\title{
Unveiling a surprising diversity in the lichen genus Micarea (Pilocarpaceae) in Réunion (Mascarenes archipelago, Indian Ocean)
}

\section{A. Maarten BRAND, Pieter P. G. VAN DEN BOOM and Emmanuë1 SÉRUSIAUX}

\begin{abstract}
Detailed anatomical and chemical studies conducted on recent collections made in almost all suitable habitats on Réunion, a small remote tropical island in the Indian Ocean, yielded a surprising diversity in the widespread lichen genus Micarea (Pilocarpaceae, Lecanorales). Twenty-one species are recognized, including 13 described here as new to science. They are: Micarea alectorialica, M. bebourensis, M. borbonica, M. boryana, M. cilaoensis, M. hyalinoxanthonica, M. isidiosa, M. melanoprasina, M. pseudocoppinsii, $M$. pseudolignaria, M. sublithinella, M. takamakae and M. tenuispora. Notes on local ecology and important biogeographical features are also given and a key to the species is provided. Isidiiform areolae are reported for the first time in the genus (M. isidiosa and M. tenuispora), as well as the production of protolichesterinic and confluentic acids (M. sublithinella and M. takamakae, respectively). Two groups within the genus are species-rich on the island: the $M$. peliocarpa group with possibly 5 species, including 3 new to science, and the $M$. prasina group with 4 species, including 2 new to science. Micarea levicula is reported here for the first time since its description, and the status of the material that can be referred to M. micrococca s. lat. needs further study.
\end{abstract}

Key words: lichen diversity, lichenized Ascomycota, new species, Southern Hemisphere, taxonomy, tropical habitats

Accepted for publication 16 September 2013

\section{Introduction}

The species is the fundamental unit of any study on the biodiversity and ecosystems of our planet, and yet, many groups of organisms have only a small fraction of their species formally described (Gaston 2000). Fungi as a major phylum present in almost all biomes represent a remarkable example: the number of species is expected to be much higher than a million, while only 100000 are currently described (Blackwell 2011; Hawksworth 2012). We performed detailed anatomical and chemical studies of lichen material recently collected in Réunion (a small and remote island in the Indian Ocean) in a

A. M. Brand: Klipperwerf 5, 2317 DX, Leiden, The Netherlands.

P. P. G. van den Boom: Arafura 16, NL-5691 JA, Son, The Netherlands.

E. Sérusiaux (corresponding author): Evolution and Conservation Biology Unit, University of Liège, Sart Tilman B22, B-4000 Liège, Belgium.

Email: E.Serusiaux@ulg.ac.be widespread and speciose genus (Micarea Fr., Pilocarpaceae, Lecanorales) to describe each species and formulate a sound taxonomic treatment of all species found in this limited, but very diverse, territory in the tropics. By showing that the genus Micarea is speciesrich in Réunion, with many undescribed species, we provide further data for the better assessment of the total number of undescribed lichen taxa (Lücking et al. 2009; Bass \& Richards 2011).

Although there are many species of Micarea in the Southern Hemisphere, the few monographic treatments of the genus, however masterful, have addressed only European species (Coppins 1983, 2009; Czarnota 2007). Molecular inferences resolved the genus into different clades and thus it is polyphyletic (Andersen \& Ekman 2005; Sérusiaux et al. 2010; Schmull et al. 2011): M. crassipes is the type species of the distantly related genus Helocarpon, M. sylvicola and its relatives belong to the Psoraceae, and all other species form a supported but poorly resolved clade 
with all accessions of the Ectolechiaceae and the Pilocarpaceae s. str. nested into it. Further phylogenetic studies with several loci are therefore needed before a well-supported delimitation of the genus can be adopted.

Phylogenetic inferences from $\mathrm{mtSSU}$ sequences (Czarnota \& Guzow-Krzemińska 2010) were used to investigate the species delimitation within the well-known, albeit notoriously difficult, Micarea prasina group. Three lineages were resolved within $M$. micrococca, two being formally recognized at species level [M. byssacea (Th. Fr.) Czarnota et al. and M. micrococca (Körb.) Gams ex Coppins s. str.]. This study assumed that a phylogenetic tree produced with data from a single locus can disentangle a difficult group of species, whereas gene trees represent 'local optima' that require additional tests and appropriate statistical methods to yield a robust species tree (Maddison 1997; Edwards 2008; Knowles \& Kubatko 2010; Camargo et al. 2012a, b; Carstens et al. 2013). It nevertheless demonstrates that the variation within the $M$. prasina group is quite substantial and requires detailed investigation.

Even when excluding the species that belong elsewhere in the Lecanorales, the genus is very diverse and occurs on all continents, including the Antarctic, and its diversity is estimated at c. 90 species (Coppins 2009). The area best sampled and studied is certainly Europe (Czarnota 2007; Coppins 2009). Asia (from the western Himalaya to Japan) and tropical mountains in the three continents represent unexplored and highly promising biomes for studying the diversity of the genus.

Réunion is a small island of $2512 \mathrm{~km}^{2}$ in the Indian Ocean, part of the Mascarene archipelago along with two other islands, Mauritius and Rodrigues. It has a volcanic origin, and one of the most active volcanoes in the world (Piton de la Fournaise) is located on its eastern side, with an elevation of $2631 \mathrm{~m}$. Otherwise it is a serrated mountain range (highest point at $3069 \mathrm{~m}$ at the Piton des Neiges), dissected in huge 'cirques' and very deep gorges. Its position in the tropical zone makes its climate warm and seasonal, although the temperature can be quite low at high elevations. A working list of lichen species found on the island was published recently (van den Boom et al. 2011), based on collections gathered over the last 15 years. A total of 463 taxa were recorded, including several rare species, large expansion of the distribution range for others, and the detection of an austral element (species whose distribution range is limited to the Southern Hemisphere). Finally, analysis of the status of species endemic to the island pointed to the urgent need for taxonomical studies in speciose and poorly known genera. Micarea is one of these and the taxonomy of species found on the island is the aim of this paper.

\section{Materials and Methods}

This study is mainly based on extensive collections of Micarea, made by the authors on the island in 2008, and hosted in LG and the private herbaria of the first two authors (h refers to the private herbarium of the collector). Further specimens gathered in 2009 by one of us (ES), with Nicolas Magain, were also included. Anatomical data were gathered and measured in dilute $\mathrm{KOH}$ for conidia and paraphyses width, and on material mounted in water for all other characters. In each collection, $c .5$ well-developed ascospores representing the size and shape variation detected, conidia and paraphyses were measured up to $0 \cdot 1 \mu \mathrm{m}$ accuracy using camera lucida drawings.

Chemical compounds were studied using several methods: medulla under UV light; melting point and microcrystallization; thin-layer chromatography (TLC) using solvent system A (toluene/1,4-dioxane/acetic acid 180:45:5) or C (toluene/acetic acid 170:30) when gyrophoric acid was expected (Huneck \& Yoshimura 1996; Orange et al. 2010) and visualization of spots with sulphuric acid sprayed over the plates, followed by heating at $110^{\circ} \mathrm{C}$ for c. $5 \mathrm{~min}$. Insoluble pigments are characterized following the classification of Meyer \& Printzen (2000).

\section{Results}

\section{Chemical compounds}

Here we present data on the chemical compounds detected in our material. Details are provided only for unusual compounds or those that can be difficult to distinguish. The numeral in TLC rubric refers to the height, measured in $\mathrm{mm}$, after a $45 \mathrm{~mm}$ run; $\mathrm{H}$ refers to the spot colour after charring in $\mathrm{H}_{2} \mathrm{SO}_{4}$; $\mathrm{U} 2$ refers to UV examination at $254 \mathrm{~nm}$, 
while U3 refers to $360 \mathrm{~nm}$; and finally extract description refers to acetone extraction on a microscope slide.

Methoxymicareic acid (Elix et al. 1984) = prasina A (sensu Coppins 1983): TLC 26; U2+, U3 \pm white ("blue-white" in Coppins 1983); H yellow-brown; U3 after charring dark brown; crystals not melting on heating (or only after prolonged boiling).

Micareic acid (Elix et al. 1984) = prasina B (sensu Coppins 1983): TLC 26; U2+, U3 \pm white ("blue" but less than prasina A in Coppins 1983); H (orange-) yellow; U3 after charring vivid yellow; crystals melting on gentle heating.

Prasinic acid (Elix et al. 1984) = prasina C (sensu Coppins 1983): TLC 24; U2+, U3 \pm white ("grey or pale mauve" or "colourless" in Coppins 1983, depending on solvent system used); $\mathrm{H}$ grey; U3 after charring dark blue-grey; extract soon milky by forming rod-shaped crystals.

Methylhiascic acid: TLC 12; U2+ grey, U3-; $\mathrm{H}$ grey; can only be separated from gyrophoric acid by TLC in solvent C (Orange et al. 2010), not in A. It was found in Micarea borbonica sp. nov. and M. peliocarpa.

Unknown $1=$ unknown in $M$. melanoprasina sp. nov.: TLC 31; U2+, U3-; $\mathrm{H}$ pale greenish grey; U3 after charring light greenish grey; crystals melting on gentle heating, soon recrystallizing; extract clear, gummy, without crystals; a substance probably related to micareic acid.

Unknown 2 = most probably confluentic acid, or a related compound, detected in $M$. takamakae sp. nov.: TLC 24; U2+, U3-; $\mathrm{H}$ pale yellowish with greyish rim; extract gummy, with radial wrinkles, later turning milky.

Unknown 3 = unknown in M. pseudolignaria sp. nov.: TLC 28; U2+, U3-; H yellowbrown (as in methoxymicareic acid); U3 after charring dark brown (as in methoxymicareic acid); extract clear, gummy, white within the ring, amorphous, not polarizing; small crystals in thallus not melting.

Besides the well-known compound argopsin and a xanthone that we tentatively refer to as thiophanic acid, two compounds are worth mentioning: alectorialic acid, diagnostic for M. alectorialica sp. nov., and a fatty acid (protolichesterinic acid) reported here for the first time in the genus and diagnostic for M. sublithinella sp. nov. Another fatty acid, close to rangiformic acid, was also detected in $M$. alectorialica sp. nov.

Insoluble pigments have been characterized by Meyer \& Printzen (2000); the following have been detected in our material ( $\mathrm{H}$ being the reaction to $\mathrm{HCl}$, and $\mathrm{N}$ to $\mathrm{HNO}_{3}$ ):

Cinereorufa-green: bright aeruginose, $\mathrm{K}+$ green, $\mathrm{H}-, \mathrm{N}+\mathrm{red}$, found in Micarea alectorialica sp. nov., M. boryana sp. nov., $M$. incrassata, $M$. isidiosa sp. nov., M. lignaria, M. melanoprasina sp. nov., M. pseudocoppinsii sp. nov., M. pseudolignaria sp. nov., M. takamakae sp. nov. and M. tenuispora sp. nov. In $M$. borbonica sp. nov., M. cilaoensis sp. nov., $M$. cinerea, $M$. peliocarpa and M. pseudocoppinsii sp. nov., the same pigment is detected but has a slightly different colour (greyish blue and not bright aeruginose as in other species) and is a surface incrustation of hyphae and not diffuse in the hymenial gelatine (as in other species). We consider it a variant of the Cinereorufa-green that requires further investigation.

Laurocerasi-brown: pale reddish brown, $\mathrm{K}+$ purple-brown, $\mathrm{H}-, \mathrm{N}-$, found in Micarea bebourensis sp. nov.

Sedifolia-grey: greyish, $\mathrm{K}+$ violet, found in Micarea hedlundii and M. prasina.

Superba-brown: pale brown, K+ dull brown, found in Micarea incrassata.

Unknown 4: violet-red, $\mathrm{K}+$ green, $\mathrm{H}$-, forming dark blue granules in $\mathrm{N}$ which get more greenish when further applying $\mathrm{K}$, found in the hymenium of Micarea isidiosa sp. nov. The granules are quite similar to those found in Lecidea hypnorum but, in this species, they do not require application of $\mathrm{N}$ to be detected.

Unknown 5: this substance can be detected at the goniocysts centre of Micarea hedlundii as tiny oily drops, which are not soluble in acetone, and therefore cannot be analyzed with TLC. 
Additional brown pigment(s) that lack characteristic reactions and have thus not been classified by Meyer \& Printzen (2000) were also observed.

In several species (Micarea bebourensis sp. nov., $M$. boryana sp. nov., $M$. levicula, $M$. melanoprasina sp. nov. and M. prasina), and in some collections of others (M. isidiosa sp. nov., M. lignaria and $M$. pseudolignaria sp. nov.), the thallus hyphae are I+ light blue after soaking in $\mathrm{KOH}$ (hemiamyloid); the reaction is often weak and not always constant. Such a hemiamyloid reaction has also been detected in many European species of $\mathrm{Mi}$ carea but, to our knowledge, has never been found in other genera of the Lecanorales.

\section{Taxonomy (Table 1)}

We could detect and delimit 21 species in our material, out of which only eight can be assigned to an already described species; the other 13 are thus described as new to science in this paper. A key for their identification is presented below.

Two subgeneric entities yielded several new species and can be described as speciose groups on the island. They are the M. peliocarpa group and the $M$. prasina group (sensu Coppins 1983). The first one comprises $M$. borbonica sp. nov., $M$. boryana sp. nov., $M$. cinerea, M. peliocarpa and possibly $M$. pseudocoppinsii sp. nov., while the second includes $M$. levicula, $M$. melanoprasina sp. nov., $M$. prasina and possibly $M$. hyalinoxanthonica sp. nov. The latter group further includes material that contains methoxymicareic acid and belongs to $M$. micrococca s. lat. (Coppins 2009); its taxonomy needs further study and is not dealt with in this paper.

\section{Ecology and biogeography (Table 2)}

Interestingly, no species known so far only from the Southern Hemisphere was detected in our material, although one (M. boryana sp. nov.) seems to be close to Micarea mutabilis, described and as yet known only from Tasmania (Australia). The austral element detected in the working list of lichens present on Réunion (van den Boom et al. 2011) cannot thus be consolidated. The other species of Micarea so far restricted to the Southern Hemisphere (Coppins \& Kantvilas 1990; Kantvilas \& Elix 1994; Coppins 1999; Aptroot 2002; Fryday 2004; Cáceres et al. 2013) are: Micarea almbornii Coppins, $M$. corallothallina M. Cáceres et al., M. endoviolascens Coppins, M. intersociella (Sirt.) Coppins, $M$. magellanica (Müll. Arg.) Fryday (=M. austroternaria Coppins \& Kantvilas), M. pannarica Fryday, M. subgranulans (Vain.) Aptroot and M. subternaria (Vain.) Aptroot. Micarea poliocheila (Vain.) Aptroot, restricted to Brazil (Minas Gerais and Rio de Janeiro), has been transferred to Bilimbia by Kalb (2007).

Interestingly, habitats at the highest elevations $(>2000 \mathrm{~m}$ ), and more precisely outcrops in dry and exposed conditions above cloud level, yielded three species that are either widespread in the temperate and boreal zones of the Northern Hemisphere (M. erratica and $M$. lignaria) or bipolar, being also found in subantarctic islands (M. incrassata). Such observations demonstrate the impressive dispersion capacity of lichen species (Honegger 1993; Romeike et al. 2002).

Micarea is absent in all habitats at low elevations on the island, including the rocky shores, open and anthropogenic vegetation, recent or old lava flows, and remnants of low elevation rainforest dominated by the Sapotaceae (e.g. at the nature reserve of 'Mare Longue' near St-Philippe). Following the vegetation typology provided by Cadet (1977), Strasberg et al. (2005) and Lacoste et al. (2011), we recognized six vegetation types that accommodate species of Micarea (Fig. 1):

Montane forest with large boles of Acacia heterophylla, either in natural stands or in plantations, at $>1500 \mathrm{~m}$ elevation.

Montane forest known as 'Bois de couleurs des Hauts', easily characterized by the abundance of tree species in the genera Dombeya (Malvaceae), Monimia and Tambourissa (Monimiaceae), and others in the Euphorbiaceae, Rubiaceae, Rutaceae, Nuxia verticillata, and locally the native bamboo Nastus borbonicus and tree ferns (Cyathaea), mainly at elevations $>1300 \mathrm{~m}$. 
TABLE 1. Summary of the taxonomy adopted for material of Micarea from Réunion and substantiation of the decision taken

Species name

M. alectorialica sp. nov.

M. bebourensis sp. nov.

M. borbonica sp. nov.

M. boryana sp. nov.

M. cilaoensis sp. nov.

M. cinerea (Schaer.) Hedl.

M. erratica (Körb.) Hertel et al.

M. hedlundii Coppins

M. hyalinoxanthonica sp. nov.

M. incrassata Hedl.

M. isidiosa sp. nov.

M. levicula (Nyl.) Coppins

M. lignaria (Ach.) Held.

M. melanoprasina sp. nov.

M. peliocarpa (Anzi)

Coppins \& R. Sant.

M. prasina Fr.

M. pseudocoppinsii sp. nov.

M. pseudolignaria sp. nov.

M. sublithinella sp. nov.

M. takamakae sp. nov.

M. tenuispora sp. nov.
Substantiation of the decision taken in this study

Alectorialic acid is otherwise only present in M. magellanica and M. submilliaria which do not develop soralia

Easily recognized by its tuberculate thallus, globose and almost stipitate, light to dark brown apothecia

Close to $M$. peliocarpa and differing by its 7-septate, longer and larger ascospores

Easily recognized by its narrowly clavate to needle-like ascospores, mainly 3-septate; a member of the $M$. peliocarpa group

Easily recognized by its Lecania-like apothecia, close to $M$. denigrata which differs by its smaller macroconidia

Identical with the material from Europe available to us, except for the absence of methylhiascic acid

Identical with the material from Europe available to us

Identical with the material from Europe and East Africa available to us

Distinguished from the other two xanthone-producing species by thallus, apothecia and ascospore characters; may belong to the $M$. prasina group

Almost identical with the material from Europe available to us

Unique combination of isidiiform areolae and bacillar, 3-7-septate ascospores

A representative of the $M$. prasina group, distinguished by production of gyrophoric acid; $M$. viridileprosa differs by thallus characters and narrower ascospores

Identical with the material from Europe available to us, although TLC analysis could not be performed

A representative of the $M$. prasina group, distinguished by its conspicuous blackish prothallus and production of an unknown substance

Identical with the material from Europe available to us

Identical with the material from Europe, except for the $\mathrm{K}+$ violet pigment which is present in the hypothecium and not in the epihymenium

Differs from M. coppinsii by shorter ascospores and absence of methylhiascic acid; probably a member of the $M$. peliocarpa group

Differs from $M$. lignaria by its 1 -septate ascospores and different chemistry

Differs from $M$. lithinella by its $0-1$-septate and larger ascospores and production of protolichesterinic acid

Easily distinguished by small ascospores $(8 \cdot 8-10 \cdot 2 \times 3 \cdot 1-3 \cdot 8 \mu \mathrm{m})$ and production of confluentic acid

Unique combination of isidiiform areolae with narrowly clavate to needle-like, 3-5-septate ascospores
Wet montane thickets with tall ericoid species including Erica reunionensis, with exuberant development of ground bryophyte cover (including species of Sphagnum), at $c$. 1700-1900 m.
Open and partially grazed forests, dominated by Sophora denudata, on the SW side of the Piton de la Fournaise, at c. 1800-2000 m. Dry and exposed outcrops, at high elevations ( $>2000 \mathrm{~m}$ ) with xerophytic bryophytes. 
TABLE 2. Distribution of the representatives of the genus Micarea in the different habitats where they grow on Réunion

\begin{tabular}{|c|c|c|c|c|c|c|}
\hline $\begin{array}{l}\text { Species name } \\
\text { (all in the genus } \\
\text { Micarea) }\end{array}$ & $\begin{array}{l}\text { Montane } \\
\text { forest } \\
\text { dominated } \\
\text { by Acacia } \\
\text { heterophylla }\end{array}$ & $\begin{array}{c}\text { Montane } \\
\text { forest } \\
\text { ('Bois de } \\
\text { couleur des } \\
\text { Hauts') }\end{array}$ & $\begin{array}{l}\text { Wet } \\
\text { montane } \\
\text { ericoid } \\
\text { thickets }\end{array}$ & $\begin{array}{l}\text { Montane } \\
\text { forest } \\
\text { dominated } \\
\text { by Sophora } \\
\text { denudata }\end{array}$ & $\begin{array}{l}\text { Outcrops } \\
\text { at high } \\
\text { elevation }\end{array}$ & $\begin{array}{c}\text { Disturbed } \\
\text { habitat } \\
\text { below } 700 \mathrm{~m} \\
\text { elevation }\end{array}$ \\
\hline alectorialica & - & - & $\mathrm{X}$ & - & - & - \\
\hline bebourensis & - & $\mathrm{X}$ & - & - & - & - \\
\hline borbonica & $\mathrm{X}$ & $\mathrm{X}$ & $\mathrm{X}$ & $\mathrm{x}$ & - & - \\
\hline boryana & - & $\mathrm{X}$ & - & - & - & - \\
\hline cilaoensis & - & $\mathrm{X}$ & - & - & - & - \\
\hline cinerea & - & - & $\mathrm{X}$ & $\mathrm{X}$ & - & - \\
\hline erratica & - & - & - & - & $\mathrm{X}$ & - \\
\hline hedlundii & - & $\mathrm{X}$ & - & - & - & - \\
\hline hyalinoxanthonica & - & $\mathrm{X}$ & - & - & - & - \\
\hline incrassata & - & - & - & - & $\mathrm{X}$ & - \\
\hline isidiosa & - & - & $\mathrm{X}$ & - & - & - \\
\hline levicula & $\mathrm{X}$ & - & - & - & - & - \\
\hline lignaria & - & - & - & - & $\mathrm{X}$ & - \\
\hline melanoprasina & $\mathrm{X}$ & - & - & - & - & - \\
\hline peliocarpa & $\mathrm{X}$ & $\mathrm{X}$ & $\mathrm{X}$ & - & - & - \\
\hline prasina & $\mathrm{X}$ & - & - & - & - & - \\
\hline pseudocoppinsii & $\mathrm{X}$ & - & - & - & - & - \\
\hline pseudolignaria & - & - & $\mathrm{x}$ & - & - & - \\
\hline sublithinella & $\mathrm{X}$ & $\mathrm{X}$ & - & - & - & - \\
\hline takamakae & - & - & - & - & - & $\mathrm{X}$ \\
\hline tenuispora & - & $\mathrm{X}$ & - & - & - & - \\
\hline
\end{tabular}

The numbers of species of Micarea found in each habitat are presented in Table 2 . As expected, the most diverse habitat is the montane forest 'Bois de couleurs des Hauts' with nine species, including five new species which have only been found here (M. bebourensis $\mathrm{sp}$. nov., $M$. boryana sp. nov., $M$. cilaoensis sp. nov., $M$. hyalinoxanthonica sp. nov. and $M$. tenuispora sp. nov.). It is immediately followed by the Acacia heterophylla forests, with seven species. The soft, rather acidic, quickdrying and often peeling bark of that endemic tree seems to be a very suitable habitat for many species of Micarea. The wet ericoid thickets shelter six species, with two species new to science ( $M$. alectorialica sp. nov. and $M$. isidiosa sp. nov.) being restricted to it. Furthermore, the Sophora open forest has only two species, including $M$. borbonica sp. nov. which is the only species present in all types of montane forest. The most distinctive M. takamakae sp. nov. is only known from a non-montane forest habitat.
Like many isolated islands and archipelagos all over the world, Réunion's original biota has been devastated by human impact and the local fauna and flora are much altered by exotic species; therefore conservation evaluation and planning require detailed studies of biodiversity processes (Lagabrielle et al. 2009). In Réunion, the native vascular flora is estimated at c. 500 species and more than 3500 have been introduced, 62 being highly invasive (Baret et al. 2006). The question may therefore arise regarding the status of lichen species observed on the island: are some species exotic? Although we have no clue at all to support this hypothesis, the question may be relevant for species growing on introduced tree species, such as Cryptomeria japonica, a species widely planted on Réunion. The case of three newly described species, $M$. boryana, $M$. cilaoensis and $M$. tenuispora, is illustrative as they have been detected only on trunks of Cryptomeria. However, the acidic and peeling bark of this tree makes it a suitable habitat for 

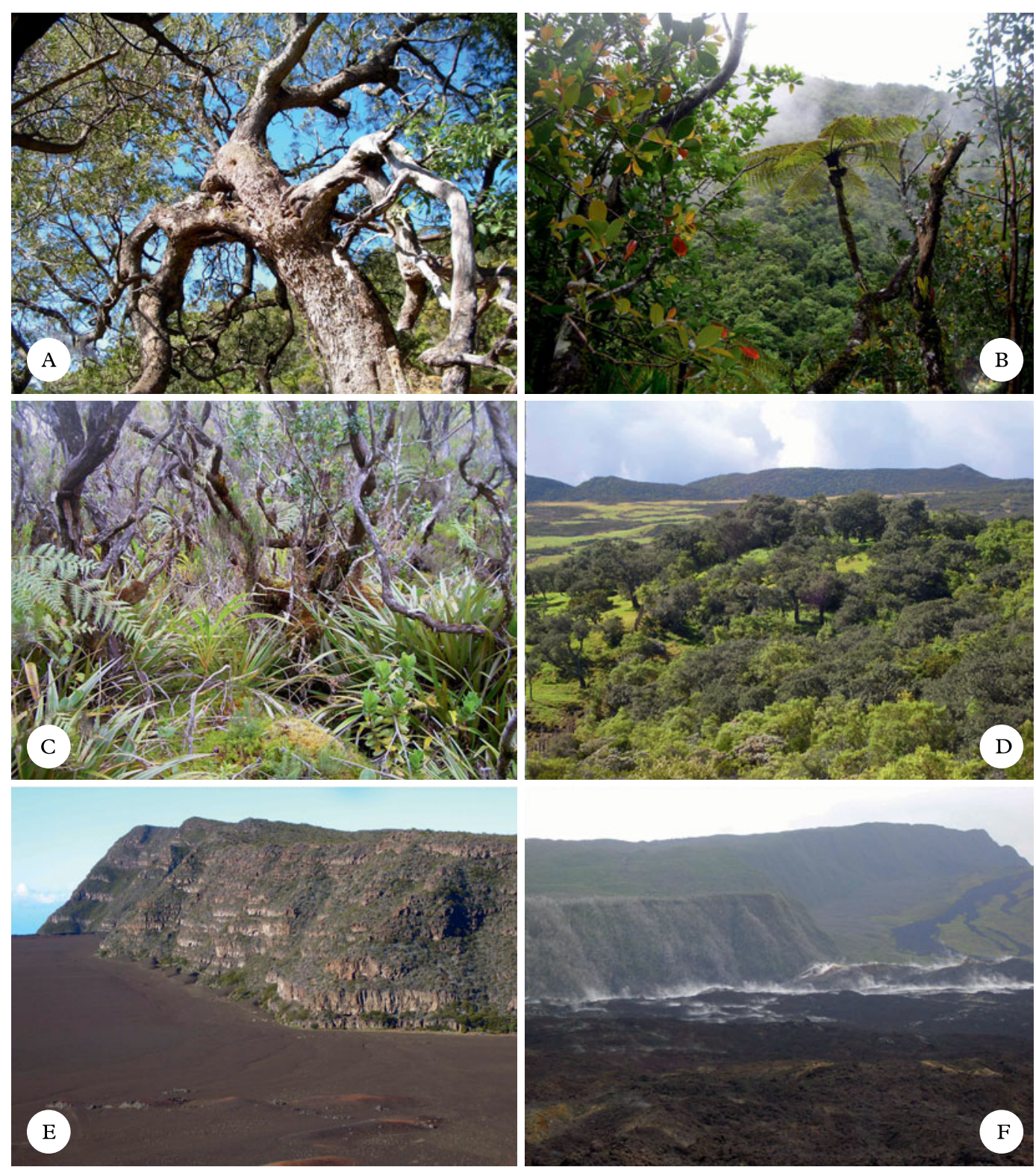

FIG. 1. Photographs of the main habitats for Micarea on Réunion.

A, typical peeling trunk of Acacia heterophylla, near Savane Cimetière (NNW of Piton de la Fournaise): seven species of Micarea were found in this habitat; B, typical view of understorey of the montane 'Bois de couleurs des Hauts' (Forêt de Bébour): the richest habitat for Micarea with nine species; C, wet montane ericoid thickets with Erica reunionensis (along the track from Bélouve to Caverne Dufour): six species occur in this spectacular habitat, including one new species with soralia and producing alectorialic acid, and one new species with isidia; D, open forest dominated by Sophora denudata, along road to Bourg Murat (WNW of Piton de la Fournaise): only two species were found in this habitat, including the new M. borbonica, the most ubiquitous species on the island; E, exposed outcrops at high elevations near the Piton de la Fournaise: three species occur in such habitats: M. erratica, M. lignaria, both widespread in the Northern Hemisphere, and M. incrassata, a bipolar species; F, lava flow of April 2007 within the 'Enclos', photographed in May 2008: no species of Micarea were found on old or recent lava flows at low elevation. In colour online. 
pioneer and fast-growing taxa such as $\mathrm{Mi}$ carea, and is also easy to sample. We therefore postulate that these three species are native to Réunion. That Micarea grows easily on planted Cryptomeria is also observed in the Azores, an archipelago in the North Atlantic Ocean with a high rainfall level and a much degraded vegetation, where Cryptomeria is also widely planted (Purvis \& James 1993).

\section{Key to the species of Micarea in Réunion}

1 Thallus with gyrophoric acid or alectorialic acid, $\mathrm{C}+\mathrm{red} \ldots \ldots \ldots \ldots$

Thallus without gyrophoric and alectorialic acids, $\mathrm{C}-$ or $\mathrm{C}+$ orange $\ldots \ldots \ldots 12$

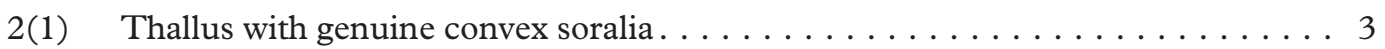

Thallus not sorediate $\ldots \ldots \ldots \ldots \ldots \ldots \ldots \ldots \ldots$

3(2) Thallus with alectorialic acid (K+ yellow, $\mathrm{P}+$ yellow) . . . . . . M. alectorialica Thallus with gyrophoric acid $(\mathrm{K}-, \mathrm{P}-) \ldots \ldots \ldots \ldots$ M. pseudocoppinsii

4(2) Thallus with, or entirely made of, isidiiform areolae, ascospores long and narrow

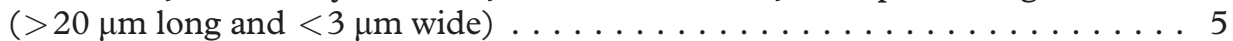

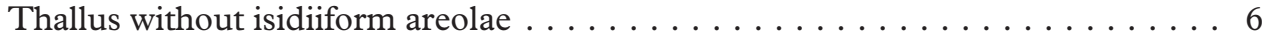

5(4) Ascospores bacillar, straight to slightly curved; aeruginose hymenium contrasting with reddish purple hypothecium . . . . . . . . . . . M. isidiosa Ascospores acicular; hymenium colourless and hypothecium pale brown to dark

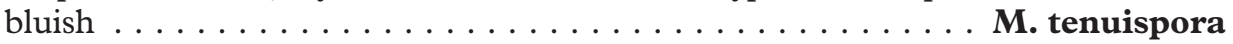

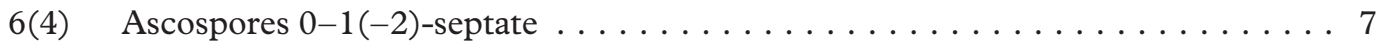

Ascospores 3-septate or more . . . . . . . . . . . . . . . . . 9

7(6) Thallus formed of vivid green goniocysts; apothecia white . . . . . . M. Mevicula Thallus not formed of goniocysts; apothecia white or grey to brown . . . . . . 8

8(7) Thallus thin, uneven; macroconidia $38-48 \mu \mathrm{m} \ldots \ldots \ldots \ldots \ldots$. . . . . cilaoensis Thallus tuberculate; macroconidia unknown . . . . . . . . M. bebourensis

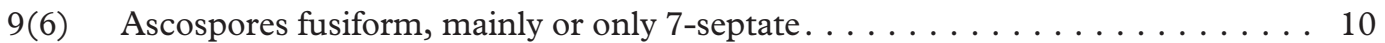
Ascospores mainly or only 3 -septate. . . . . . . . . . . . . . 11

10(9) Ascospores 3.4-4.4 $\mu \mathrm{m}$ wide; macroconidia $57-78 \times 1 \cdot 2-1.5 \mu \mathrm{m} \ldots$. . M. cinerea Ascospores 3.0-4.1 $\mu \mathrm{m}$ wide; macroconidia 30-40 $\times 1 \cdot 0-1 \cdot 3 \mu \mathrm{m}$

M. borbonica

11(9) Ascospores fusiform, 3.6-4.7 $\mu \mathrm{m}$ wide, less than $17 \mu \mathrm{m}$ long . . . . M. peliocarpa Ascospores narrowly clavate to needle-like, $2 \cdot 0-2 \cdot 5 \mu \mathrm{m}$ wide, more than $17 \mu \mathrm{m}$ long M. boryana

12(1) Thallus with xanthones, C+ orange-yellow . . . . . . . M. hyalinoxanthonica Thallus without xanthones, $\mathrm{C}-\ldots \ldots \ldots \ldots \ldots$

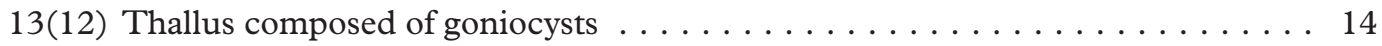

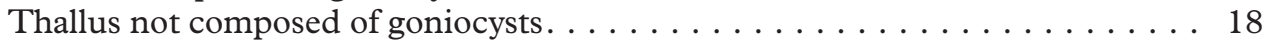

14(13) Pycnidia stipitate, with tiny hairs, thallus with $\mathrm{K}+$ violet pigment . . . M. hedlundii Pycnidia not stipitate, without hairs, or pycnidia absent . . . . . . . . 15

15(14) Thallus with conspicuous black prothallus; presence of Cinereorufa-green pigment in thallus and apothecia and unknown pigment in apothecia . . M. melanoprasina Thallus without dark prothallus . . . . . . . . . . . . . 16 
16(15) Apothecia dark; micareic or confluentic acid present. . . . . . . . . . . . 17

Apothecia whitish to brownish; methoxymicareic acid present. . . . . . . . . . . .

M. micrococca s. lat. (not treated)

17(16) Apothecia with $\mathrm{K}+$ violet pigment; micareic acid present. . . . . . . . . M. prasina Apothecia without $\mathrm{K}+$ violet pigment but epihymenium blue-green, $\mathrm{K}-$; confluentic

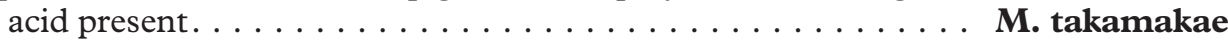

18(13) Ascospores (1-)3-7-septate . . . . . . . . . . . . . . . . . . M. lignaria Ascospores 0-1-septate . . . . . . . . . . . . . . . . . . . . . . . . . 19

19(18) Saxicolous; no lichen substances. . . . . . . . . . . . . . . . . . . 20

Corticolous or terricolous; lichen substances present . . . . . . . . . 21

20(19) Apothecia marginate, up to $0.4 \mathrm{~mm}$ diam.; epihymenium aeruginose . . . . . . . . .

M. erratica

Apothecia immarginate, up to $0.6 \mathrm{~mm}$ diam., epihymenium brown, locally with bluegreen pigment . . .................... incrassata

21(19) Ascospores 13-15 $\times 5-6 \mu \mathrm{m}$; protolichesterinic acid present . . . M. sublithinella Ascospores 8-9 $\times 3-4 \mu \mathrm{m}$; chemistry different, not a fatty acid .

M. pseudolignaria

\section{The Species}

\section{Micarea alectorialica Brand, van den Boom \& Sérus. sp. nov.}

\section{MycoBank No.: MB807670}

Thallus areolate, sorediate, soralia to $0.6 \mathrm{~mm}$ diam.; apothecia convex, up to $0.7 \mathrm{~mm}$, shining black; ascospores fusiform, $17-20 \times 4 \cdot 5-5 \cdot 6 \mu \mathrm{m},(1-) 3$-septate; production of alectorialic acid.

Type: Réunion, Forêt de Bébour, path from Bélouve to cabane Dufour, $21^{\circ} 5 \cdot 10^{\prime} \mathrm{S}, 55^{\circ} 31 \cdot 36^{\prime} \mathrm{E}, 1890 \mathrm{~m}$, wet montane ericoid thickets, on Erica, 2 June 2008, M. Brand 58863 (LG-holotype; hb. v.d. Boom, hb. Brand-isotype).

\section{(Fig. 2A)}

Thallus $c .5 \mathrm{~cm}$ across, formed by dispersed areolae; areolae first globose, $0 \cdot 1-0.2 \mathrm{~mm}$ across, pale-coloured, then bursting into a soralium; soralia to $0 \cdot 6(-0 \cdot 8) \mathrm{mm}$ diam., convex, sometimes aggregated to almost stipitate, white to light greenish; soredia $25-35 \mu \mathrm{m}$. Photobiont micareoid, cells c. 5.0-5.5 $\mu \mathrm{m}$. Cortex absent, but in young areolae upper layer with more crystals; soredia strongly inspersed with crystals (alectorialic acid).

Apothecia up to $0.7 \mathrm{~mm}$ diam., shining black, convex without margin, often complex, and then made of fused small apothecia. Excipulum bluish in outer parts, inside pale, formed by strongly conglutinated radiating hyphae. Hypothecium pale or light bluish. Hymenium c. $55 \mu \mathrm{m}$ high; epihymenium dark blue. Paraphyses c. $1.5 \mu \mathrm{m}$ thick, apically branched and anastomosing. Asci clavate, c. $46 \times 12 \mu \mathrm{m}$, tholus of the Micarea-type. Ascospores 8 per ascus, fusiform $17 \cdot 0-20 \cdot 0 \times$ 4.5-5. $6 \mu \mathrm{m},(1-) 3$-septate.

Micropycnidia numerous, superficial between areolae, black, c. $70 \mu \mathrm{m}$; microconidia narrow, fusiform with tapering ends, 6.6$8.3 \times 0.9-1.0 \mu \mathrm{m}$.

Chemistry. Alectorialic acid ( $\mathrm{K}+$ yellow, $\mathrm{P}+$ yellow, C+ red) in thallus and soralia; fatty acid also present (extract as rangiformic acid, but larger agglomerations). Pigment in thallus and apothecia belonging to Cinereorufagreen.

Etymology. The new species is named after the chemical compound that makes this species easy to recognize amongst the species of Micarea present on Réunion.

Habitat and distribution. On Erica stems at $1900-2000 \mathrm{~m}$, in wet montane ericoid thickets, abundant.

Notes. Alectorialic acid is rare amongst species of Micarea as it is so far detected in 

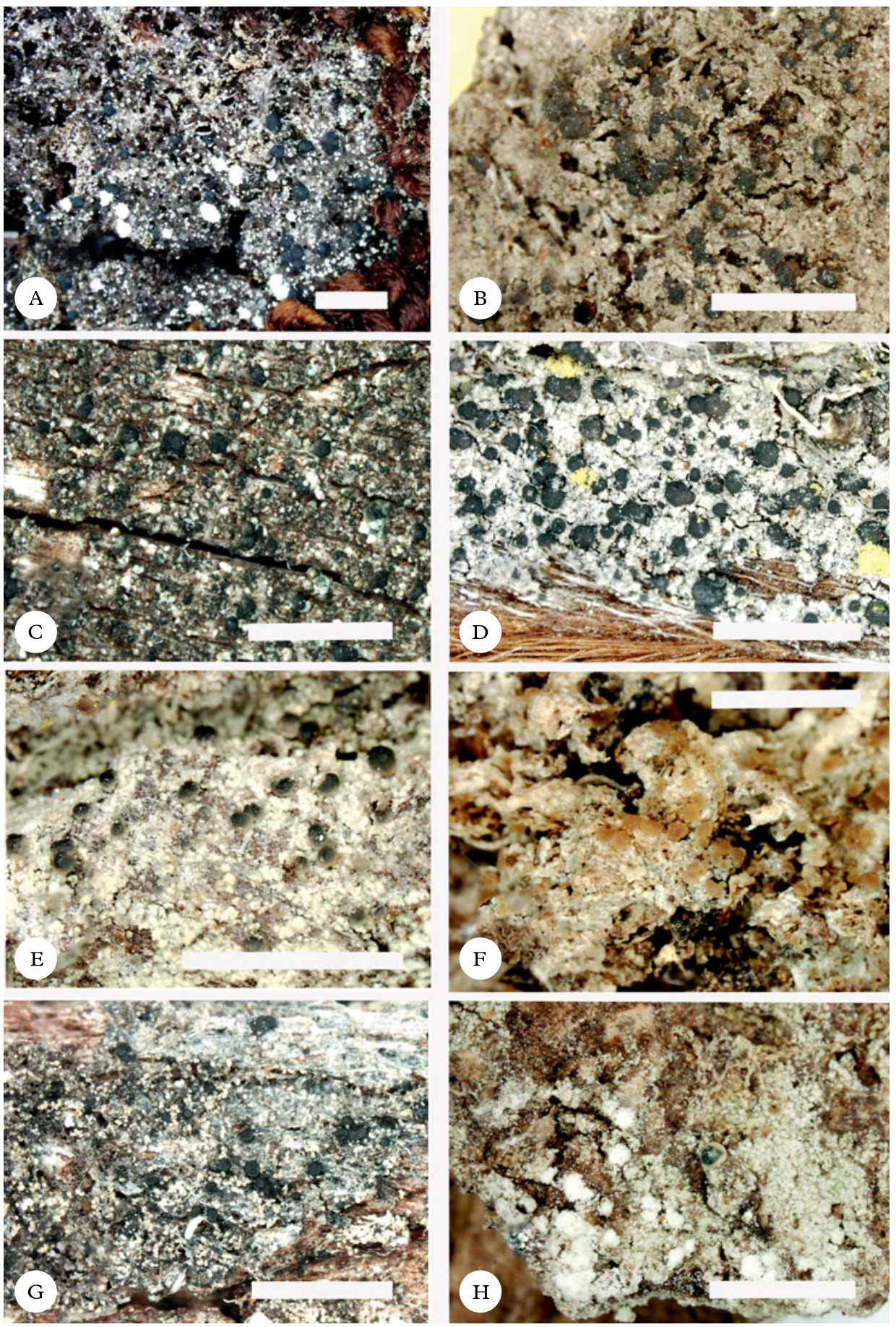

FIG. 2. Photographs of the new species described from Réunion. A, Micarea alectorialica sp. nov. (holotype); B, M. bebourensis sp. nov. (holotype); C, M. borbonica sp. nov. (holotype); D, M. boryana sp. nov. (holotype); E, M. cilaoensis sp. nov. (holotype); F, M. hyalinoxanthonica sp. nov. (holotype); G, M. isidiosa sp. nov. (holotype); H, M. pseudocoppinsii sp. nov. (holotype). Scale $=1 \mathrm{~mm}$. In colour online. 
only two species: M. magellanica (Müll. Arg.) Fryday (=M. austroternaria Coppins \& Kantvilas) restricted to the Southern Hemisphere (Coppins \& Kantvilas 1990; Fryday 2004), and M. submilliaria (Nyl.) Coppins, a mostly Northern Hemisphere species (Coppins 2009), but both do not produce soralia, although the surface of the latter is usually eroding to form sorediate patches. Only three other species of Micarea produce soralia: M. coppinsii Tønsberg, M. pseudocoppinsii (here described as new) and $M$. viridileprosa Coppins \& van den Boom (soralia usually not clearly delimited and forming a leproid surface); they can all be distinguished by the production of gyrophoric acid (van den Boom \& Coppins 2001; Coppins 2009).

Additional specimen examined. Réunion: same locality as the type, $21^{\circ} 05^{\prime} 31^{\prime \prime} \mathrm{S}, 55^{\circ} 30^{\prime} 41^{\prime \prime} \mathrm{E}, 1910-2000 \mathrm{~m}$, wet ericoid thickets with $E$. reunionensis and Phylica nitida, on Erica, 9 xi 2009, N. Magain E E. Sérusiaux s. n. (LG).

\section{Micarea bebourensis Brand, van den Boom \& Sérus. sp. nov.}

\section{MycoBank No.: MB807671}

Thallus typically tuberculate when young, tubercles $0 \cdot 10-0 \cdot 15 \mathrm{~mm}$ across; apothecia up to $0.6 \mathrm{~mm}$, greyish brown; ascospores ovate to shortly bacillar, 11-14 $\times$ 3.3-4.3 $\mu \mathrm{m}, 1(-3)$-septate; production of gyrophoric acid.

Type: Réunion, Forêt de Bébour, trail to Cassé de Takamaka, $21^{\circ} 07 \cdot 5^{\prime} \mathrm{S}, 55^{\circ} 34 \cdot 5^{\prime} \mathrm{E}, 1340 \mathrm{~m}$, wet montane rainforest, on rotting standing trunk, 1 June 2008, $P$. van den Boom 40344 (LG-holotype; hb. v.d. Boom, hb. Brand-isotype).

(Fig. 2B)

Thallus up to $2 \mathrm{~cm}$ diam., pale to brownish greyish or greenish, uneven, typically tuberculate when young, with tubercles $0 \cdot 10$ $0.15 \mathrm{~mm}$ broad and high, eventually formed of coarse and agglomerated granules, first pale, eventually breaking up at the top of tubercules or at the margins of granules, and forming a rough blue-grey surface (resembling tiny soralia, but no genuine soredia are formed). Cortex absent, often with thin, clear epinecral layer. Photobiont micareoid. Thallus filled with crystals (gyrophoric acid).

Apothecia up to $0.6 \mathrm{~mm}$ diam, light to dark greyish brown, often unevenly coloured (partly dark, partly pale), almost globose, with constricted base. Excipulum greyish brown in outer parts, pale inside. Hypothecium pale (reddish) brown, conglutinate. Hymenium c. 50-60 $\mu \mathrm{m}$ high; epihymenium patchily brownish. Paraphyses 0.7-1.1 $\mu \mathrm{m}$ thick, branched and strongly anastomosing; some paraphyses with a thickened apex $(1.8 \mu \mathrm{m})$. Asci cylindrical, c. $40-53 \times 10 \mu \mathrm{m}$, tholus of the Psora-type. Ascospores 8 per ascus, ovate to shortly bacillar, $11-14 \times 3 \cdot 3-4.3 \mu \mathrm{m}, 1(-3)$ septate.

Micropycnidia inconspicuous, immersed, with brownish top, c. $35 \mu \mathrm{m}$. Microconidia bacillar with rounded ends, some slightly curved, 5.9-7.1 $\times 0 \cdot 9-1 \cdot 1 \mu \mathrm{m}$.

Chemistry. Gyrophoric acid (K-, $\mathrm{P}-, \mathrm{C}+$ red), mainly in the thallus, epihymenium, excipulum and pycnidia wall. Brownish pigment belonging to Laurocerasi-brown, in epihymenium, slightly brownish, $\mathrm{K}+$ purplebrown; subhymenium and hymenium in $\mathrm{K}$ slightly rose-coloured.

Etymology. This new species is named after the Bébour forest, one of the largest and best preserved montane forests on Réunion, where many interesting lichen species grow.

Habitat and distribution. On introduced tree species, including Cryptomeria japonica and decaying wood, in lower montane forest at $1200-1500 \mathrm{~m}$.

Notes. The almost globose apothecia, sometimes almost stipitate, and the thallus tubercles (best observed in young thalli) represent the most obvious characters to distinguish this species. Its generic assignment to Micarea is questionable as the asci are cylindrical (not clavate as in other species of the core group of Micarea) and the tholus is much akin to the Psora-type (sensu Ekman et al. 2008). The anatomy of apothecia (globose apothecia with a constricted base and development of excipular tissue) makes it close to Micarea lignaria and M. pseudolignaria sp. nov.; M. bebourensis is easily differentiated from both by the absence of an aeruginose pigment and the production of gyrophoric acid. 
Additional specimens examined. Réunion: same locality as the type, P. van den Boom 40370 (h); Bélouve, $21^{\circ} 3 \cdot 74^{\prime} \mathrm{S}, 55^{\circ} 32 \cdot 29^{\prime} \mathrm{E}, 1500 \mathrm{~m}$, montane forest, on planted Cryptomeria, 2008, M. Brand 58215 (h); Plainedes-Palmistes, Ravine Sèche, $21^{\circ} 8 \cdot 63^{\prime} \mathrm{S}$, $55^{\circ} 35 \cdot 31^{\prime} \mathrm{E}$, $1200 \mathrm{~m}$, planted exotic trees in sheltered valley, on Cryptomeria, 2008, M. Brand 58141 (h); Forêt de Bébour, path W of Col de Bébour, $21^{\circ} 07 \cdot 2^{\prime} \mathrm{S}$, $55^{\circ} 33 \cdot 6^{\prime} \mathrm{E}, 1490$ $\mathrm{m}$, Cryptomeria plantation, on Cryptomeria, 2008, P. van den Boom 40322 (h).

\section{Micarea borbonica Brand, van den Boom \& Sérus. sp. nov.}

\section{MycoBank No.: MB807672}

Thallus small, to $1.5 \mathrm{~cm}$, dull white to pale greenish; apothecia up to $0.5 \mathrm{~mm}$ diam., whitish to pale brownish or pale to dark bluish grey; ascospores fusiform with rounded ends, $15-27 \times 3 \cdot 0-4 \cdot 1 \mu \mathrm{m}, 3-7$-septate; macroconidia strongly and repeatedly curved sigmoid, 30 $42 \times 1 \cdot 0-1 \cdot 3 \mu \mathrm{m}$, indistinctly 3 -septate; production of gyrophoric acid.

Type: Réunion, WNW of Piton de la Fournaise, along road to Bourg Murat, $21^{\circ} 11 \cdot 9^{\prime} \mathrm{S}, 55^{\circ} 36 \cdot 9^{\prime} \mathrm{E}, 1970 \mathrm{~m}$, small forest with Sophora denudata trees, on Sophora, 4 June 2008, P. van den Boom 40644 (LG-holotype; hb. v.d. Boom, hb. Brand-isotype).

\section{(Fig. 2C)}

Thallus small, to $1.5 \mathrm{~cm}$ across, dull white to pale greenish, uneven, c. $50 \mu \mathrm{m}$ high or consisting of small granules, some of them resembling small isidia. Upper part c. $15 \mu \mathrm{m}$ without algae, of loosely interwoven hyphae. Photobiont micareoid, cells c. $5 \mu \mathrm{m}$, photobiont layer inspersed with crystals (gyrophoric acid).

Apothecia up to $0.2-0.5 \mathrm{~mm}$ diam., whitish to pale brownish or pale to dark bluish grey, often coloured only partially, with pale margin, flat or slightly convex to almost globose, adnate with constricted base. Excipulum pale or bluish grey in outer parts, pale inside. Hypothecium colourless. Hymenium c. $55 \mu \mathrm{m}$ high; epihymenium colourless or partly blue-grey. Paraphyses 1.3-1.6 $\mu \mathrm{m}$ thick, branched and anastomosing. Asci clavate, $33-40 \times 12-15 \mu \mathrm{m}$, tholus of the Micarea-type. Ascospores 8 per ascus, fusiform with rounded ends, $15-27 \times 3 \cdot 0-4 \cdot 1$ $\mu \mathrm{m},(3-) 7$-septate, often curved.

Macropycnidia not rare, globose, 100$140 \mu \mathrm{m}$, top often blue-grey; macroconidia strongly and repeatedly curved sigmoid (when observed under unpressed cover slip), 30-42 × 1.0-1.3 $\mu \mathrm{m}$ (measured under pressed cover slip), faintly 3-septate. Micropycnidia inconspicuous, semi-superficial, $c$. $35 \mu \mathrm{m}$, pale. Microconidia narrow fusiform with tapering ends, $5-7(-10) \times 0 \cdot 8-1 \cdot 0 \mu \mathrm{m}$.

Chemistry. Gyrophoric and methylhiascic acids ( $\mathrm{K}-, \mathrm{P}-, \mathrm{C}+\mathrm{red})$, mainly in thallus, hymenium, excipulum and pycnidia. Pigment in apothecia belonging to Cinereorufa-green.

Etymology. The name of this new species refers to the old name of the island, 'Ile Bourbon' in French. It is indeed characteristic of all habitats, natural or anthropogenic, in the montane forest zone of the island.

Habitat and distribution. On native and exotic trees (Acacia heterophylla, Cryptomeria, Sophora denudata, Platanus and on branches of Erica), and decorticated wood, between 800-2000 m.

Notes. Ascospores in this new species are typically 7-septate, although 3-6-septate ones can be found usually in immature or poorly developed apothecia. Micarea borbon$i c a$ is closely related to $M$. peliocarpa, a species also found in Réunion; it differs in having convex to subglobose areoles, longer and narrower ascospores $(13 \cdot 6-17 \cdot 0 \times 3 \cdot 6-4 \cdot 7$ $\mu \mathrm{m}$ in collections of $M$. peliocarpa from Réunion), and is usually 7-septate (mostly 3septate in $M$. peliocarpa). A further related species is $M$. cinerea, also found on Réunion, that can be distinguished by larger spores (24$30 \times 3 \cdot 4-5 \cdot 0 \mu \mathrm{m})$ and much longer macroconidia $(57-78 \times 1.2-1.5 \mu \mathrm{m})$. See further notes under $M$. cinerea and $M$. peliocarpa.

Additional specimens examined. Réunion: Piton de la Fournaise, $0.5 \mathrm{~km} \mathrm{NW}$ of Gîte du Volcan, $21^{\circ} 12 \cdot 07^{\prime} \mathrm{S}$, $55^{\circ} 41.53^{\prime} \mathrm{E}, 2040 \mathrm{~m}$, mixed wood on N-slope, on Acacia heterophylla, 2008, M. Brand 58361, 58376 (h); Plaine-des-Palmistes, $21^{\circ} 6 \cdot 98^{\prime} \mathrm{S}, 55^{\circ} 37 \cdot 13^{\prime} \mathrm{E}, 1100 \mathrm{~m}$, Platanus branches in garden, 2008, M. Brand 58696 (h); ibid., on decorticated wood of telegraph pole, 2008, P. van den Boom 40621 (h); Cilaos, Forêt du Grand Matarum, path to Cabane Dufour, $21^{\circ} 7 \cdot 08^{\prime} \mathrm{S}$, $55^{\circ} 29 \cdot 19^{\prime} \mathrm{E}, 1770 \mathrm{~m}$, wet montane ericoid thickets on steep SW slope, on thin twigs, 2008, M. Brand 59713 (h); WNW of Piton de la Fournaise, along road to Bourg Murat, $21^{\circ} 11 \cdot 6^{\prime} \mathrm{S}, 55^{\circ} 37 \cdot 5^{\prime} \mathrm{E}, 2090 \mathrm{~m}$, disturbed wood with Sophora denudata, on Sophora, P. van den Boom 40665 (h); ESE of Le Tampon, NNE of Petite-île, $21^{\circ} 18 \cdot 9^{\prime} \mathrm{S}, 55^{\circ} 35 \cdot 4^{\prime} \mathrm{E}, 800 \mathrm{~m}$, open place with mature 
Cryptomeria trees, on Cryptomeria, 2008, P. van den Boom 40806 (h).

\section{Micarea boryana Brand, van den Boom \& Sérus. sp. nov.}

\section{MycoBank No.: MB807673}

Thallus areolate, greenish to greyish brown, eroding when old; apothecia to $0 \cdot 4(-0 \cdot 6) \mathrm{mm}$, grey to bluish black; ascospores narrowly clavate to needle-like, 16$27 \times 2 \cdot 0-2 \cdot 5 \mu \mathrm{m},(1-) 3(-4)$-septate; production of gyrophoric acid.

Type: Réunion, Cirque de Cilaos, $\mathrm{N}$ of Cilaos, Forêt du Grand Matarum, trail to Caverne Dufour, $21^{\circ} 07 \cdot 3^{\prime} \mathrm{S}$, $55^{\circ} 29 \cdot 2^{\prime} \mathrm{E}$, montane forest, $1420 \mathrm{~m}$, on Cryptomeria, 31 May 2008, P. van den Boom 40264 (LG-holotype; hb. v.d. Boom, hb. Brand-isotype).

(Fig. 2D)

Thallus up to $5 \mathrm{~cm}$ across, greenish to greyish brown, continuous, made of small flat to convex or even subglobose areolae, with a thin endo- to epiphloeodal dark bluish black prothallus made of narrow hyphae, colourless or partly dark brownish or bluish hyphae. Areolae either flat $(0 \cdot 1-0.6 \mathrm{~mm}$ broad, 0.05 $\mathrm{mm}$ thick) or subglobose (granules c. $0 \cdot 1$ $\mathrm{mm}$ across), eroding at the margins in old thalli, slightly shiny. Cortex absent, but a thin, clear epinecral layer can be observed. Photobiont micareoid, cells c. 5-8 $\mu \mathrm{m}$. Thallus filled with crystals of gyrophoric acid.

Apothecia up to $0 \cdot 4(-0 \cdot 6) \mathrm{mm}$ diam., grey to bluish black, sometimes with a pale margin, first flat, without a distinct margin, then semiglobose. Excipulum with radiating hyphae, varying in colour (often in same apothecium) from pale to superficially bluish and centrally light brown. Hypothecium pale or brownish. Hymenium c. 30-55 $\mu \mathrm{m}$ high; epihymenium patchily greyish-bluish. Paraphyses $1 \cdot 0-1 \cdot 2$ $\mu \mathrm{m}$ thick, branched and anastomosing. Asci 25-37 $\times 10-15 \mu \mathrm{m}$, tholus of the Micareatype. Ascospores 8 per ascus, in one bundle, narrowly clavate to needle-like, $16 \cdot 0-27 \cdot 0 \times$ $2 \cdot 0-2 \cdot 5 \mu \mathrm{m},(1-) 3(-4)$-septate, sometimes apically slightly enlarged and tapering towards their basal ends.

Mesopycnidia often present and conspicuous, sessile, c. 160-230 $\mu \mathrm{m}$ diam. and 200$270 \mu \mathrm{m}$ in height, dark brownish, with white blob of conidia on top; pigment brown to greenish brown or aeruginose, $\mathrm{K}-$; wall with crystals of gyrophoric acid, mainly near the apex. Mesoconidia ovate, $4.0-4.5 \times(1 \cdot 3-)$ 1.5-1.6 $\mu \mathrm{m}$. Micropycnidia rarely present, inconspicuous, with a dark brownish wall. Microconidia fusiform, 4.0-4.5(-5.0) $\times 1 \cdot 0$ $1 \cdot 1 \mu \mathrm{m}$.

Chemistry. Gyrophoric acid ( $\mathrm{K}-, \mathrm{P}-, \mathrm{C}+$ red) detected in thallus, but also in pale parts of apothecia and in mesopycnidia. Pigment in thallus and apothecia belonging to Cinereorufa-green. Brown pigment in hypothecium $\mathrm{K}+$ reddish to purple-brown.

Etymology. This new species is named after the French officer and first lichen collector on the island, J. B. G. M. Bory de SaintVincent (1778-1846) who described several spectacular and now well-known species, such as Cladonia candelabrum, C. giganteum, Lobaria retigera, Stereocaulon vulcani and Sticta ambavillaria.

Habitat and distribution. Found at several localities on the island, between 1200-1500 $\mathrm{m}$, always epiphytic on the exotic Cryptomeria japonica.

Notes. We first assigned these collections to Micarea mutabilis Coppins \& Kantvilas, described from Tasmania (Coppins \& Kantvilas 1990). According to the original description, the latter, however, clearly differs by several important characters: absence of prothallus, larger asci $(40-50 \times 9-10 \mu \mathrm{m})$, ascospores longer and more septate [21-41 $\times$ 2.2-3.0 $\mu \mathrm{m}$; (1-)5-7(-8)-septate], absence of conspicuous pycnidia producing mesoconidia (the mesoconidia described for that species are actually microconidia). We believe such discrepancies are worth species recognition. Other species with needle-shaped or acicular ascospores are (Coppins 2009): Micarea globulosella (Nyl.) Coppins, distinguished by its black and subglobose apothecia and smaller ascospores [(10-)12-19(-24) $\times$ $2 \cdot 0-2 \cdot 5(-3 \cdot 0) \mu \mathrm{m}] ; M$. synotheoides (Nyl.) Coppins distinguished by the absence of chemical compounds and variable ascospores [needle-like, fusiform to rod-shaped, (0-) 1-3-septate, $14-35(-43) \times 1 \cdot 8-2 \cdot 5(-3 \cdot 0)$ $\mu \mathrm{m}]$; M. pycnidiophora Coppins \& P. James, together with $M$. stipitata Coppins \& P. 
James, both being easily recognized by their numerous, stipitate pycnidia; and finally $M$. tenuispora sp. nov., described here as new from Réunion, which is easily recognized by its isidiiform thallus areolae.

Additional specimens examined. Réunion: same locality as the type, 2008, P. van den Boom 41041 (h); Plainedes-Palmistes, Ravine Sèche, $21^{\circ} 8 \cdot 63^{\prime} \mathrm{S}, 55^{\circ} 35 \cdot 31^{\prime} \mathrm{E}$, $1200 \mathrm{~m}$, planted exotic trees in wood in sheltered valley, on Cryptomeria, 2008, M. Brand 58141, 58146 (h), P. van den Boom 39776 (h); Bélouve, $21^{\circ} 3 \cdot 74^{\prime} \mathrm{S}, 55^{\circ} 32 \cdot 29^{\prime} \mathrm{E}$, $1500 \mathrm{~m}$, disturbed montane forest, on Cryptomeria, 2008, M. Brand 58206 (h).

\section{Micarea cilaoensis Brand, van den Boom \& Sérus. sp. nov.}

\section{MycoBank No.: MB807675}

Thallus thin, uneven, consisting of slightly convex granules, green; apothecia to $0.4 \mathrm{~mm}$, adnate, with constricted base; ascospores ovoid to ellipsoid, 11-12 $\times$ $4 \cdot 0-4 \cdot 4 \mu \mathrm{m}, 0-1$-septate; production of gyrophoric acid.

Type: Réunion, Cirque de Cilaos, Forêt du Grand Matarum, trail to Caverne Dufour, $21^{\circ} 07 \cdot 3^{\prime} \mathrm{S}$, $55^{\circ} 29 \cdot 2^{\prime} \mathrm{E}, 1420 \mathrm{~m}$, montane forest, on Cryptomeria, 31 May 2008, P. van den Boom 40230 (LG-holotype; hb. v.d. Boom, hb. Brand-isotype).

(Fig. 2E)

Thallus rather extensive ( $3 \mathrm{~cm}$ across), green, thin $(65-90 \mu \mathrm{m})$, uneven, made of slightly convex granules. Cortex absent. Photobiont micareoid, cells $c$. 5-9 $\mu \mathrm{m}$. Photobiont layer inspersed with crystals of gyrophoric acid.

Apothecia up to $0.4 \mathrm{~mm}$ diam., whitish to greyish with pale margin, flat or slightly convex, adnate with constricted base. Excipulum well developed, made of thin reticulate hyphae, filled with crystals, colourless. Hypothecium colourless. Hymenium c. 35-42 $\mu \mathrm{m}$ high; epihymenium colourless or faintly greenish grey, in $\mathrm{K}$ unchanged or locally brownish. Paraphyses $1.3 \mu \mathrm{m}$ thick, branched and anastomosing. Asci clavate, c. $28 \times 12 \mu \mathrm{m}$, tholus of the Micarea-type. Ascospores 8 per ascus, ovoid to ellipsoid, $11-12 \times 4 \cdot 0-4 \cdot 4 \mu \mathrm{m}, 0$ 1-septate.

Pycnidia not rare, superficial or semiimmersed, white, ampulliform, c. $150 \mu \mathrm{m}$ diam., top with crystals; macroconidia straight or more or less curved, $38-48 \times 0 \cdot 9-1 \cdot 1$ $\mu \mathrm{m}$, non-septate, cylindrical with rounded ends; in same pycnidia, microconidia can be found: microconidia bacilliform, $5 \cdot 2-7 \cdot 1 \times$ $0 \cdot 9-1 \cdot 1 \mu \mathrm{m}$.

Chemistry. Gyrophoric acid (K-, P-, C+ red) detected in thallus, hymenium, excipulum, pycnidia. Pigment in apothecia belonging to Cinereorufa-green.

Etymology. The name chosen for this new species refers to the most spectacular cirque on the island, the Cirque de Cilaos, where this rare species has been discovered.

Habitat and distribution. Known from a single locality, on the exotic Cryptomeria japonica at the margin of disturbed natural forest, at $1420 \mathrm{~m}$ elevation.

Notes. Micarea cilaoensis could be confused with a species of Lecania because of its apothecia with a brownish disc and whitish margin, and its well-developed excipulum. However, examination of the hamathecium and ascustype immediately point to the genus Micarea. Also remarkable are the large ampulliform pycnidia producing macro- and microconidia together. Micarea cilaoensis is close to $M$. denigrata (Fr.) Hedl., a widespread species in the Northern Hemisphere which also produces large ampulliform pycnidia; the latter differs by its narrower ascospores [(7-)9-16(-18) $\times 2 \cdot 0-3 \cdot 3(-3 \cdot 5) \mu \mathrm{m}]$ and much smaller macroconidia $(12-24 \times c .1 \mu \mathrm{m}$; Coppins 2009).

Additional specimen examined. Réunion: same locality as the type, P. van den Boom 40229 (h, hb Brand 62255).

\section{Micarea cinerea (Schaer.) Hedl.}

Thallus up to $c .1 \mathrm{~cm}$ across, made of small granules (c. $0 \cdot 1-0.2 \mathrm{~mm}$ diam.), some of them resembling small isidia, white to pale grey.

Apothecia to $0.3 \mathrm{~mm}$ diam., whitish, beige, pale yellowish brown or dark bluish grey, often unevenly coloured, with a slightly pale margin, flat or convex to almost globose, adnate with constricted base. Hymenium $c$. $50 \mu \mathrm{m}$; epithecium yellowish or more rarely bluish, K-. Hypothecium hyaline. Asci 37$45 \times 15-20 \mu \mathrm{m}$, tholus of the Micareatype. Ascospores 8 per ascus, fusiform, 24$30 \times 3 \cdot 4-5 \cdot 0 \mu \mathrm{m},(3-) 7$-septate, straight to often curved. 
Pycnidia large, c. $200 \mu \mathrm{m}$ diam., partly immersed in areoles. Macroconidia long and slightly flexuose, $7-10$-septate, $57-78 \times 1 \cdot 2-$ $1.5 \mu \mathrm{m}$.

Chemistry. Gyrophoric acid (K-, P-, C+ red), mainly in thallus, hymenium, excipulum and pycnidia wall; methylhiascic acid absent. Pigment in apothecia belonging to Cinereorufa-green.

Habitat and distribution. On Erica in wet montane ericoid thickets at $2000 \mathrm{~m}$, and on trunk of Sophora at similar elevation.

Notes. In European collections of this species, methylhiascic acid is detected as well as gyrophoric acid; this acid has not been detected in the material from Réunion. See further data under M. borbonica. Micarea cinerea is a widespread species as it occurs in Europe, North and Central America, Asia and Australia (Tasmania), according to Coppins (2009).

Specimens examined. Réunion: Forêt de Bébour, trail from Gîte de Bélouve, $3.5 \mathrm{~km}$ to the south-west, to Caverne Mussard, $21^{\circ} 05 \cdot 3^{\prime} \mathrm{S}, 55^{\circ} 31 \cdot 3^{\prime} \mathrm{E}, 1980 \mathrm{~m}$, wet montane ericoid thickets, $1980 \mathrm{~m}$, on Erica, 2008, P. van den Boom 40526, 40555 (h, hb Brand 61471); WNW of Piton de la Fournaise, along road to Bourg Murat, $21^{\circ} 11 \cdot 9^{\prime} \mathrm{S}, 55^{\circ} 36 \cdot 9^{\prime} \mathrm{E}$, small open forest with Sophora denudata, on Sophora, 1970 m, 2008, P. van den Boom 40644A (h).

\section{Micarea erratica (Körb.) Hertel et al.}

Thallus of scattered whitish areoles; areolae up to $0.5 \mathrm{~mm}$ diam., with a $c .15 \mu \mathrm{m}$ thick epinecral layer. Photobiont not micareoid, cells to $15 \mu \mathrm{m}$.

Apothecia up to $0.4 \mathrm{~mm}$ broad, black, flat, with a distinct margin. Excipulum of conglutinated radiate hyphae, outer part aeruginose, inner part hyaline. Hypothecium dark brown. Hymenium c. $25 \mu \mathrm{m}$; epihymenium aeruginose. Paraphyses simple, c. $1.8 \mu \mathrm{m}$ thick. Asci c. $25 \times 10 \mu \mathrm{m}$, tholus of the Micarea-type. Ascospores 8 per ascus, narrowly ellipsoid, c. $7 \times 3 \mu \mathrm{m}$.

Mesopycnidia numerous, c. 70-100 $\mu \mathrm{m}$, immersed, upper side dark bluish, lower side unpigmented. Mesoconidia c. 3.2-4.5 $\times$ $1 \cdot 1-1.9 \mu \mathrm{m}$.
Chemistry. No lichen substances detected.

Habitat and distribution. On volcanic rocks in meadow, at c. $2000 \mathrm{~m}$ elevation.

Notes. This single collection falls within the variation of European specimens of that species, including the size and height of apothecia, and we have no doubt it belongs to the widespread $M$. erratica. The species has been recognized as the sole representative of the new genus Leimonis (Harris 2009), an option not retained so far (Coppins 2009).

Specimen examined. Réunion: track Bourg Murat to Piton de la Fournaise, $21^{\circ} 12 \cdot 63^{\prime} \mathrm{S}, 55^{\circ} 36 \cdot 57^{\prime} \mathrm{E}, 1970$ $\mathrm{m}$, volcanic rock outcrops in meadow on NW slope, on stones, 2008, M. Brand 59027 (h).

\section{Micarea hedlundii Coppins}

Thallus less than $1 \mathrm{~cm}$ across, made of abundant and aggregated goniocysts, forming coralloid masses, dark greenish to greyish. Goniocysts 17-32 $\mu \mathrm{m}$ diam., locally with coarse crystals. Hyphae partly with browngrey pigment ( $\mathrm{K}+$ violet). Photobiont micareoid, c. $5 \mu \mathrm{m}$.

Apothecia absent.

Pycnidia stipitate; stipe $0.24-0.40 \mathrm{~mm}$ high, 100-160 $\mu \mathrm{m}$ thick, surface with loose, curly, grey tomentum, made of $c .1 .7 \mu \mathrm{m}$ thick hyphae; pycnidia $c .140 \mu \mathrm{m}, 1-3(-5)$ on a stipe. Mesoconidia elliptic, c. $4 \cdot 2-5 \cdot 2 \times$ $1 \cdot 6-2 \cdot 1 \mu \mathrm{m}$.

Chemistry. Unknown 5 at the centre of goniocysts, and Sedifolia-grey.

Habitat and distribution. On soft rotting wood of standing trunks in montane forest, at $1400-1900 \mathrm{~m}$ elevation.

Notes. Apothecia are absent in our material from Réunion, but otherwise we could not detect any differences with available collections from Western Europe, from the Albertine Rift in Africa and most recent descriptions (Czarnota 2007; Coppins 2009). The recently described $M$. tomentosa Czarnota \& Coppins (Czarnota 2007), known from central and northern Europe (Suija et al. 2008), also has stalked pycnidia but differs by the complete absence of pigment $\mathrm{H}$ in the goniocysts. 
Specimens examined. Réunion: Cilaos, Forêt du Grand Matarum, along path to Cabane Dufour, $21^{\circ} 6 \cdot 29^{\prime} \mathrm{S}$, $55^{\circ} 29 \cdot 58^{\prime} \mathrm{E}, 1870 \mathrm{~m}$, low forest on steep SW slope, on Dombeya tree, 2008, M. Brand 59739 (h); Forêt de Bébour, trail to Takamaka, $21^{\circ} 05 \cdot 9^{\prime} \mathrm{S}, 55^{\circ} 34 \cdot 3^{\prime} \mathrm{E}$, $1370 \mathrm{~m}$, wet rainforest, on rotting standing trunk, 2008, P. van den Boom 40883 (h).-_Rwanda: Virunga volcanoes, southern flank of the Karisimbi, c. 3400 m, open forest with Hagenia abyssinica and Hypericum revolutum, on big bole of Hagenia, 1974, f. Lambinon 74/1524 (LG; confirmed by B. J. Coppins, 1992); ibid., $01^{\circ} 29^{\prime} 12 \cdot 56^{\prime \prime} \mathrm{S}, 029^{\circ} 28^{\prime} 37 \cdot 38^{\prime \prime} \mathrm{E}$, c. $3200 \mathrm{~m}$, on Hagenia, x 2010, E. Sérusiaux s. n. (LG).

\section{Micarea hyalinoxanthonica Brand, van den Boom \& Sérus. sp. nov.}

\section{MycoBank No.: MB807676}

Thallus thin, pale greenish, made of goniocysts; apothecia up to $0.6 \mathrm{~mm}$, adnate pale beige, translucent when wet; ascospores bacillar, $13 \cdot 2-17 \cdot 0 \times 3 \cdot 2-3.6 \mu \mathrm{m}$, 3septate; production of xanthone (thallus and apothecia C+ orange).

Type: Réunion, Forêt de Bébour, Sentier de Takamaka, $21^{\circ} 06 \cdot 48^{\prime} \mathrm{S}, 55^{\circ} 34 \cdot 02^{\prime} \mathrm{E}, 1380 \mathrm{~m}$, low trees in montane forest, on Dombeya, 7 June 2008, M. Brand 59293 (LG-holotype; hb. v.d. Boom, hb. Brand-isotype).

\section{(Fig. 2F)}

Thallus c. $3 \mathrm{~cm}$ diam., pale greenish, thin, overgrowing decaying bryophytes, soft, felty, made of small (20-30 $\mu \mathrm{m}$ diam.) goniocysts. Photobiont micareoid, 5-8 $\mu \mathrm{m}$, individually surrounded with a mantle of furcate hyphae, partly aggregated in goniocysts; thallus also with strait, thick-walled hyphae $(c .2 \mu \mathrm{m})$ and sometimes including crystals.

Apothecia abundant, $0 \cdot 1-0 \cdot 5(-0 \cdot 6) \mathrm{mm}$ diam., adnate with constricted base, pale beige, translucent when wet, rarely greyish, first flat, with hardly distinct margin, then convex. Excipulum thin, chondroid, with thin, branching hyphae, outer parts sometimes with protruding hyphae, giving a hairy appearance. Hypothecium pale or patchily light brownish. Hymenium c. $50 \mu \mathrm{m}$ high, strongly conglutinated, colourless. Paraphyses c. 1.3 $\mu \mathrm{m}$ thick, branched and anastomosing. Asci clavate, c. $45-50 \times 12 \mu \mathrm{m}$; tholus of $\mathrm{Mi}$ carea-type. Ascospores 8 per ascus, bacillar, $13 \cdot 2-17.0 \times 3 \cdot 2-3.6 \mu \mathrm{m}, 3$-septate, distinctly constricted at septa, with more or less globose cells.

Pycnidia absent.
Chemistry. Xanthone (thiophanic acid?) in thallus and apothecia ( $\mathrm{K}+$ yellow; $\mathrm{P}-, \mathrm{C}+$ and $\mathrm{KC}+$ orange). Crystals in thallus and apothecia, in streaks in hymenium and excipulum.

Etymology. The name chosen combines the chemical compound produced by this new species and a diagnostic character of its apothecia, being translucent when wet.

Habitat and distribution. Only known from the type locality. It grows on decaying liverworts on bole of a Dombeya in rainforest (c. $1400 \mathrm{~m})$.

Notes. Young globose apothecia of no more than $100 \mu \mathrm{m}$ diam. contain already ripe asci. TLC gives the same result as with Micarea xanthonica Coppins \& Tønsberg, which contains thiophanic acid (Coppins \& Tønsberg 2001). This species can be distinguished by its thallus entirely made of dense goniocysts, very similar to that of $M$. prasina, apothecia rare or even absent, and ascospores $(0-) 1(-3)$-septate. A further species containing xanthone is Micarea isabellina Coppins \& Kantvilas, so far only known from Tasmania, growing on rocks or terricolous (Coppins \& Kantvilas 1990). It can be distinguished by its areolate to irregularly warty thallus, black apothecia and larger ascospores (19-26× 3.5-4.0 $\mu \mathrm{m})$. Furthermore, M. hyalinoxanthonica can be distinguished by its ascospores that are distinctly constricted at septae, with more or less globose cells.

\section{Micarea incrassata Hedl.}

Thallus c. $2 \mathrm{~cm}$ across, composed of dispersed to adjacent areolae on rock, overgrowing mats of cyanophyta (Stigonema); areolae beige greenish, globose to convex, 0.1-0.2 mm. Photobiont micareoid, cells c. 5 $\mu \mathrm{m}$. Cortex absent, thallus without crystals. Genuine cephalodia absent, but thallus clearly associated with Stigonema, the cells of which are clearly intermingled with hyphae within the areolae.

Apothecia up to $0.6 \mathrm{~mm}$ diam., black, convex without margin. Excipulum hardly distinct from hymenium. Hypothecium dark brown. 
Hymenium c. $40 \mu \mathrm{m}$ high; epihymenium brown, locally with blue-green pigment. Paraphyses c. $1.8 \mu \mathrm{m}$ thick, mostly simple, occasionally branched. Asci clavate, c. 27-30 × 8-10 $\mu \mathrm{m}$, tholus of the Micarea-type. Ascospores 8 per ascus, ellipsoid, 8.6-10.0 $\times 4 \cdot 2-5.0 \mu \mathrm{m}$, non-septate, wall c. $0.3 \mu \mathrm{m}$ thick.

Micropycnidia scarce, between areolae, wall dark brown, c. $60 \mu \mathrm{m}$; microconidia bacillar, $5 \cdot 7-6.8 \times 1 \cdot 0-1 \cdot 1 \mu \mathrm{m}$.

Chemistry. No lichen substance. Pigment in thallus and apothecia belonging to Cinereorufa-green, pigment in hypothecium belonging to Superba-brown.

Habitat and distribution. Only known from a single collection, on recently exposed volcanic rock at high elevation.

Notes. Our single collection is very close to the European material of Micarea incrassata that we could examine. It differs, however, by its constantly 0 -septate ascospores (vs. 02-septate in European material), smaller asci and thus lower hymenium, and absence of a chemical compound (European material has thallus crystals, not dissolving in $\mathrm{K}$ or $\mathrm{HCl}$, but slowly in acetone). Pending further studies, we don't consider these variations to be worth taxonomic recognition.

Micarea incrassata is a further example of a species widespread in the Northern Hemisphere and also detected in Australia (New South Wales) and subantarctic islands, and that occurs patchily on summits in tropical areas. A similar example is Fuscopannaria praetermissa, present on high mountains in East Africa and in Réunion (van den Boom et al. 2011).

Specimen examined. Réunion: Piton de la Fournaise, $\mathrm{S}$ slope of Pas de Bellecombe, $21^{\circ} 12 \cdot 6^{\prime} \mathrm{S}, 55^{\circ} 41 \cdot 8^{\prime} \mathrm{E}$, $2250 \mathrm{~m}$, recent volcanic rock on steep S-slope, 2008, M. Brand 58333 (h).

\section{Micarea isidiosa Brand, van den Boom \& Sérus. sp. nov.}

\section{MycoBank No.: MB807677}

Thallus formed of isidioid granules growing on partly dark prothallus, greenish to brownish; apothecia up to $0.4 \mathrm{~mm}$ in diam, black; hypothecium purplish or reddish; ascospores bacillar, straight to slightly curved, 22.5-
$29.8 \times 2 \cdot 8-2.9 \mu \mathrm{m}, 3-7$-septate; production of gyrophoric acid.

Type: Réunion, Forêt de Bébour, path from Bélouve to cabane Dufour, $21^{\circ} 05 \cdot 10^{\prime} \mathrm{S}, 55^{\circ} 31 \cdot 36^{\prime} \mathrm{E}, 1890 \mathrm{~m}$, wet montane ericoid thickets, on Erica, 2 June 2008, $M$. Brand 58862 (LG-holotype; hb. v.d. Boom, hb. Brand-isotype).

(Fig. 2G)

Thallus up to $3 \mathrm{~cm}$ diam., greenish to brownish, discontinuous, made of small globose or isidia-like areolae on thin endo- to epiphloeodal prothallus with narrow colourless or partly brownish or bluish hyphae. Areolae first granular $(0.1 \mathrm{~mm}$ across $)$ eventually becoming isidiiform $(0.30 \times 0.05 \mathrm{~mm})$, unbranched or forked. Cortex absent. Photobiont micareoid. Thallus filled with crystals (gyrophoric acid).

Apothecia up to $0.4 \mathrm{~mm}$ diam., black, first flat, without distinct margin, then semiglobose. Excipulum with radiating hyphae, purplish, with few crystals. Hypothecium reddish or bluish. Hymenium c. $40 \mu \mathrm{m}$ high; epihymenium and hymenium intense blue-green. Paraphyses c. 1.4 $\mu \mathrm{m}$ thick, branched. Asci c. 30$34 \times 10 \mu \mathrm{m}$, tholus of the Micarea-type. Ascospores 8 per ascus, bacillar, straight to slightly curved, $22.5-29.8 \times 2.8-2.9 \mu \mathrm{m}$, 3-7-septate.

Micropycnidia inconspicuous, immersed, with dark bluish wall. Microconidia fusiform, $3.7-4.1 \times 0.9-1.0 \mu \mathrm{m}$.

Chemistry. Gyrophoric acid (K-, P-, C+ red), mainly in thallus, but also detected in apothecia. Blue pigment in thallus and apothecia $\mathrm{K}+$ intense green, $\mathrm{N}+$ red and $\mathrm{H}+$ darker, most probably belonging to Cinereorufa-green; red pigment mainly present in hymenium (unknown 4) $\mathrm{K}+$ green, $\mathrm{N}$ producing a precipitate of dark blue granules, $\mathrm{H}-$.

Etymology. The name refers to the isidioid areolae forming the thallus.

Habitat and distribution. On Erica stems in wet ericoid thickets at elevations between 1900-2000 m.

Notes. The thallus of this species seems to be isidiate; however, the 'isidia' are not 
outgrowths on a thallus or areolae as they grow directly on the prothallus; they thus represent isidiiform areolae. The thallus and apothecia of this species are much akin to those of $M$. tenuispora, also described as new in this paper; the bacillar ascospores, more vivid colours in apothecium section, with an aeruginose tinge in the epihymenium contrasting with a reddish purple hypothecium, and the unique precipitate of dark blue granules in $\mathrm{N}$ in the hymenium are the diagnostic characters.

Additional specimens examined. Réunion: Forêt de Bébour, path from Bélouve to cabane Dufour, $3 \mathrm{~km}$ from Gîte Bélouve, $21^{\circ} 05 \cdot 10^{\prime} \mathrm{S}, 55^{\circ} 31 \cdot 36^{\prime} \mathrm{E}, 1890 \mathrm{~m}$, tall ericoid thickets in montane forest, on Erica, 2008, M. Brand 58865 (h); ibid., $21^{\circ} 05 \cdot 3^{\prime} \mathrm{S}, 55^{\circ} 31 \cdot 3^{\prime} \mathrm{E}, 1980$ m, on Erica, 2008, P. van den Boom 40529 (h).

\section{Micarea levicula (Nyl.) Coppins}

Thallus diffuse, vivid green, made of delicately and finely coralloid goniocysts; goniocysts $25-53 \mu \mathrm{m}$ diam. or cylindrical (c. $50 \times$ $18 \mu \mathrm{m})$, round to ovate, often more or less angular, fused to form branched coralloid structures up to $150 \mu \mathrm{m}$ high, made of conglutinated hyphae and micareoid photobiont (cells c. $6 \mu \mathrm{m}$ ), inspersed with crystals (gyrophoric acid), locally some hyphae protrude to form low papillae on the surface.

Apothecia up to $0.5 \mathrm{~mm}$ diam., white, adnate, slightly constricted at base, without any visible margin, convex. Excipulum narrow ( $<10 \mu \mathrm{m}$ thick), formed by radiating, conglutinate hyphae; surface of excipulum sometimes rough because of protruding hyphae. Hypothecium colourless. Hymenium 50-55 $\mu \mathrm{m}$ high. Paraphyses 1.3-1.6 $\mu \mathrm{m}$ thick, branched and anastomosing. Asci c. 39-55 $\times 8-12 \mu \mathrm{m}$, tholus of the Micareatype. Ascospores 8 per ascus, ellipsoid, 10.3$10 \cdot 8 \times 3 \cdot 7-4 \cdot 1 \mu \mathrm{m}, 0-1$-septate.

Micropycnidia occasionally present, small, white; microconidia $9.8 \times 0.8 \mu \mathrm{m}$, narrow fusiform. Mesoconidia occasionally present, $5.5 \times 1.3 \mu \mathrm{m}$.

Chemistry. Gyrophoric acid ( $\mathrm{K}-, \mathrm{P}-, \mathrm{C}+$ red), crystals present only at the centre of the goniocysts.
Habitat and distribution. On natural stands of Acacia heterophylla; so far only found near the Piton de la Fournaise, where it grows with the related $M$. prasina.

Notes. Micarea levicula has been recognized as a member of the $M$. prasina group by van den Boom \& Coppins (2001), on the basis of its type and only available collection from Cuba (H-Nyl. 20762). The short description provided matches the material collected in Réunion. Micarea viridileprosa Coppins \& van den Boom, also a member of the prasina group with gyrophoric acid, differs by the loose, non-coralloid and smaller, more soredia-like goniocysts, the localization of the gyrophoric acid crystals on the outer parts of the hyphae surrounding the goniocysts, and finally by the narrower spores (c. 11-14 $\times$ $3 \cdot 0-3 \cdot 4 \mu \mathrm{m})$. Micarea viridileprosa is so far known from western Europe, where it can be quite common, and Tasmania (van den Boom \& Coppins 2001; Coppins 2009). The recently described $M$. corallothallina (Cáceres et al. 2013) from NE Brazil has a thallus made of "irregularly densely branched isidioid granules of c. $50 \mu \mathrm{m}$ thick" but can be distinguished by the absence of any chemical coumpounds.

Specimens examined. Réunion: NNW of Piton de la Fournaise, trail along Ravine Savane Cimetière, $21^{\circ} 11 \cdot 6^{\prime} \mathrm{S}, 55^{\circ} 37 \cdot 5^{\prime} \mathrm{E}, 2050 \mathrm{~m}$, mixed forest with mature Acacia heterophylla, on Acacia, 2008, E. Sérusiaux s. n. (LG), P. van den Boom 39979, 40001 (h); Piton de la Fournaise, $0.5 \mathrm{~km}$ NW of Gîte du Volcan, $21^{\circ} 12 \cdot 82^{\prime} \mathrm{S}, 55^{\circ} 41 \cdot 18^{\prime} \mathrm{E}, 2040 \mathrm{~m}$, Acacia heterophylla wood on N-slope, 2008, M. Brand 58353 (h).

\section{Micarea lignaria (Ach.) Hedl.}

Thallus consisting of small (100 $\mu \mathrm{m}$ across), convex, light grey granules over an algal layer growing on saxicolous mosses. Photobiont micareoid, cells round, $c .6 \cdot 5-8 \cdot 0 \mu \mathrm{m}$.

Apothecia c. $0.25 \mathrm{~mm}$ broad, convex, black, immarginate. Hymenium c. $60 \mu \mathrm{m}$, epihymenium blue. Ascospores 8 per ascus, fusiform, c. $20.0 \times 5.2 \mu \mathrm{m}, 5-7$-septate.

Chemistry. Pigment in apothecia belonging to Cinereorufa-green. 
Habitat and distribution. On steep rock face at $2450 \mathrm{~m}$.

Notes. This collection is very small, but all characters match those of European collections. The thallus is P+ red, but is too small for chemical analysis; the shape of crystals in the thallus is identical to that of argopsin, the lichen substance diagnostic of $M$. lignaria. The ascospores are rather small but fall within the range of European material. The species is widespread as, according to Coppins (2009), it occurs in Europe, North and South America, and Asia (Siberia).

Specimen examined. Réunion: Cilaos, path Le Bloc to cabane Dufour, Côteau de Kervéguen, $21^{\circ} 6 \cdot 72^{\prime} \mathrm{S}$, $55^{\circ} 29 \cdot 70^{\prime} \mathrm{E}, 2450 \mathrm{~m}$, basalt of W-exposed rock face, 2008, M. Brand 59904 (h).

\section{Micarea melanoprasina Brand, van den Boom \& Sérus. sp. nov.}

\section{MycoBank No.: MB807678}

Thallus to $5 \mathrm{~cm}$, pale green on black prothallus; apothecia $0 \cdot 2-0.5 \mathrm{~mm}$, dark grey to black; ascospores oval-oblong to slightly clavate, $8 \cdot 5-10 \cdot 5 \times 2 \cdot 8-4.0 \mu \mathrm{m}$, 0-1-septate; production of unkown compound.

Type: Réunion, 'Réserve naturelle de la Roche Ecrite', track to the summit, $20^{\circ} 58^{\prime} 6^{\prime \prime} \mathrm{S}, 55^{\circ} 26^{\prime} 26^{\prime \prime} \mathrm{E}$, c. $1500 \mathrm{~m}$, montane forest, on Acacia heterophylla, 4 November 2009, N. Magain E E. Sérusiaux s. n. (LGholotype; hb. v.d. Boom, hb. Brand-isotype).

(Fig. 3A \& B)

Thallus to $5 \mathrm{~cm}$ across, pale green, made of coralloid goniocysts growing on bluish black prothallus; thallus surrounded by bluish black prothallus, consisting of $c .2 \mu \mathrm{m}$ thick blueblack, irregularly intricated hyphae; goniocysts $14-30 \mu \mathrm{m}$, round to ovate, fused to form branched coralloid structures to 200 $\mu \mathrm{m}$ high, composed of conglutinated hyphae in a gelatinized matrix and micareoid photobiont (cells $c$. 4-5 $\mu \mathrm{m}$ ), inspersed with small crystals (melting in boiling water forming oily drops, recrystallizing after cooling).

Apothecia 0.2-0.5 mm diam., grey to black, adnate, without visible margin, convex. Excipulum colourless or dark blue, formed by radiating hyphae. Hypothecium pale or more or less blue-aeruginose, and brownish ( $\mathrm{K}+$ purplish brown) in lower part. Hymenium 33-37 $\mu \mathrm{m}$ high, more or less aeruginose near base; epihymenium colourless to aeruginose. Paraphyses $1.1-1.5 \mu \mathrm{m}$ thick, branched and anastomosing. Asci c. $32-35 \times 12-13 \mu \mathrm{m}$; tholus of the Micarea-type. Ascospores 8 per ascus, oval-oblong to slightly clavate, $8 \cdot 5-10 \cdot 5 \times$ $2 \cdot 8-4 \cdot 0 \mu \mathrm{m}, 0-1$-septate, septum not in middle of the spore but somewhat to the wider end (old spores occasionally 3-septate).

Micropycnidia occasionally present, small (15-30 $\mu \mathrm{m})$, immersed, colourless; microconidia shortly bacilliform, $4.0-4.5 \times 1.0 \mu \mathrm{m}$.

Chemistry. Unknown 1 in thallus (K-, $\mathrm{P}-$, C-). Pigment in thallus and apothecia belonging to Cinereorufa-green.

Etymology. The name of this new species refers to the bluish black prothallus that makes it very characteristic amongst species of the $M$. prasina group, to which it belongs.

Habitat and distribution. On trunks of trees, including Acacia heterophylla, and on branches of shrubs (Gaertnera vaginata, Chassalia coralloides, Dombeya sp.) in montane rainforest (1400-1900 m).

Notes. A distinctive species, easily recognized because of its dark prothallus and finely coralloid-goniocystose thallus, very much akin to that of M. prasina. Micarea melanoprasina is indeed related to the $M$. prasina group and can be distinguished by the presence of Cinereorufa-green in the thallus and apothecia, as well as the unnamed brown pigment in the apothecia. Micarea subviridescens (Nyl.) Hedl. has a dark bluish green thallus, made of dense aggregated goniocysts, dark apothecia, larger ascospores (10$18 \times 4-6 \mu \mathrm{m})$ and contains prasinic acid (Coppins 2009).

Additional specimens examined. Réunion: Bélouve forest, $21^{\circ} 03.93^{\prime} \mathrm{S}, 55^{\circ} 32.93^{\prime} \mathrm{E}, 1600 \mathrm{~m}$, pristine montane forest, on tree, 27 v 2008, E. Sérusiaux s. n. (LG); Bois de sans Souci, $21^{\circ} 1 \cdot 23^{\prime} \mathrm{S}, 55^{\circ} 22 \cdot 10^{\prime} \mathrm{E}, 1350 \mathrm{~m}$, montane forest, on Gaertnera vaginata, 2008, M. Brand $59994(\mathrm{~h}) ; 21^{\circ} 01 \cdot 22^{\prime} \mathrm{S}, 55^{\circ} 22 \cdot 23^{\prime} \mathrm{E}, 1380 \mathrm{~m}$, open shrub woodland, degraded montane forest, on Chassalia corallioides, 2008, M. Brand 60103 (h); E of Le Tampon, Forêt de Notre-Dame de la Paix, $21^{\circ} 15 \cdot 1^{\prime} \mathrm{S}, 55^{\circ} 36 \cdot 5^{\prime} \mathrm{E}$, 1720 m, montane forest, on Dombeya, 2008, P. van den Boom 40775 (h); Cirque de Cilaos, Forêt du Grand Matarum, along path to Cabane Dufour, $21^{\circ} 07 \cdot 04^{\prime} \mathrm{S}$, $55^{\circ} 29 \cdot 23^{\prime} \mathrm{E}, 1870 \mathrm{~m}$, montane forest, on Dombeya, 2008, M. Brand 59740 (h). 

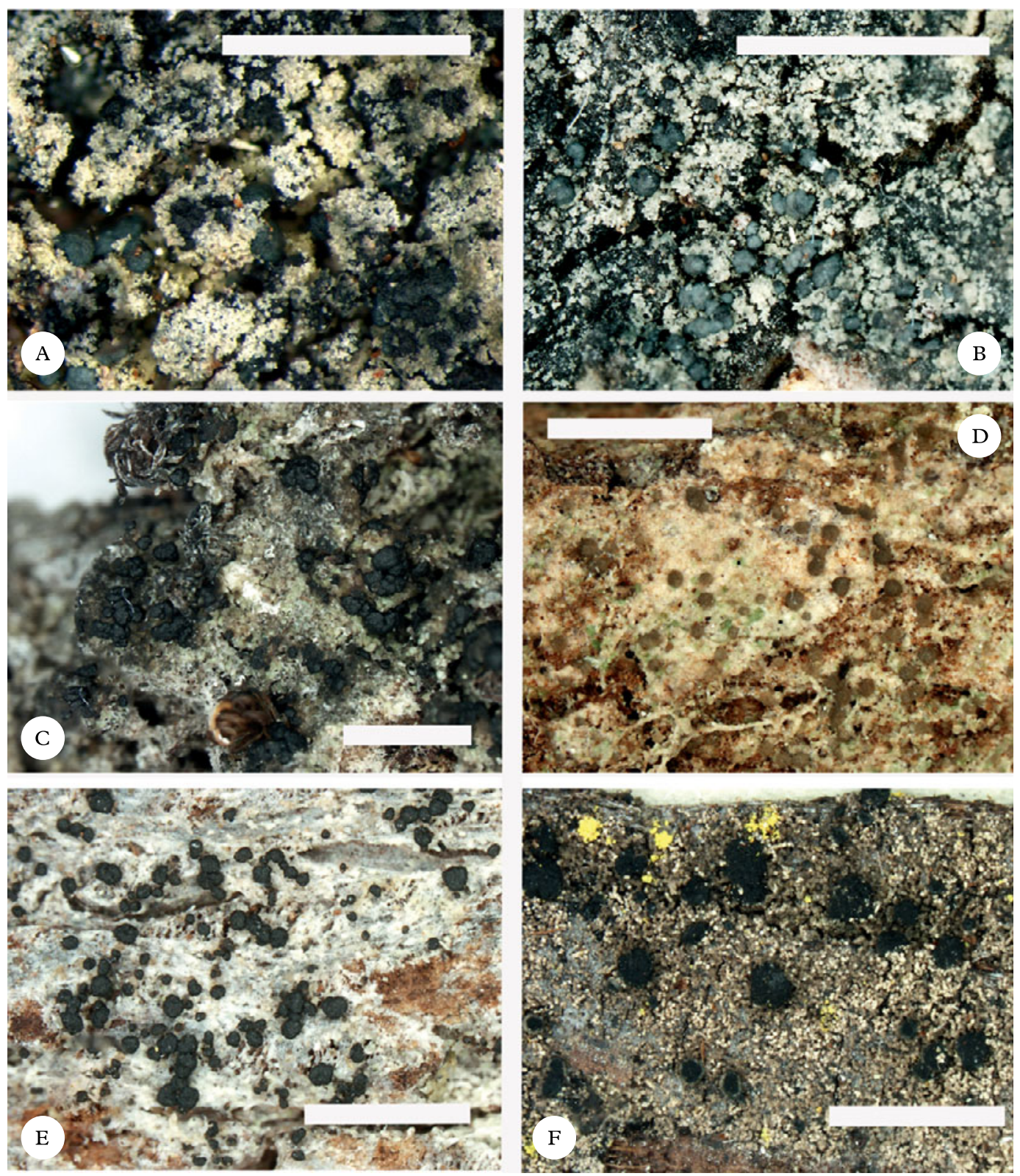

FIG. 3. Photographs of the new species of Micarea described from Réunion. A \& B, M. melanoprasina sp. nov. (holotype); C, M. pseudolignaria sp. nov. (holotype); D, M. sublithinella sp. nov. (holotype); E, M. takamakae sp. nov. (holotype); F, M. tenuispora sp. nov. (holotype). Scale $=1 \mathrm{~mm}$. In colour online.

\section{Micarea peliocarpa (Anzi) Coppins \&} R. Sant.

Thallus rather small, up to $1.5 \mathrm{~cm}$ across, pale greenish, uneven, c. $50 \mu \mathrm{m}$ high. Upper part c. $15 \mu \mathrm{m}$ without algae, of loosely interwoven hyphae. Photobiont micareoid, photobiont layer inspersed with crystals (gyrophoric acid). 
Apothecia up to $0.6 \mathrm{~mm}$ diam., whitish or dark bluish grey, often patchily coloured, with pale margin, flat or low convex, almost globose, adnate with constricted base. Outer parts of excipulum pale or bluish grey, pale inside. Hypothecium colourless. Hymenium c. 40-60 $\mu \mathrm{m}$ high; epihymenium colourless or patchily blue-grey, if pigmented then pigment also descending in hymenium. Paraphyses 1.1-1.4 $\mu \mathrm{m}$ thick, branched and anastomosing. Asci clavate, c. $35-55 \times 12-15 \mu \mathrm{m}$, tholus of the Micarea-type. Ascospores 8 per ascus, fusiform with rounded ends, 3-septate, $13 \cdot 6-17 \cdot 0 \times 3 \cdot 6-4.7 \mu \mathrm{m}$.

Macropycnidia not rare, globose, c. 120$150 \mu \mathrm{m}$, top blue-grey or not; macroconidia curved (but not spirally), 45-58 $\times 1 \cdot 1-1 \cdot 3$ $\mu \mathrm{m}$, indistinctly 3-septate. Micropycnidia rare, inconspicuous, semi-superficial, c. $45 \mu \mathrm{m}$, pale. Microconidia narrowly fusiform with tapering ends, $6.3-8.1 \times 0.7-0.9 \mu \mathrm{m}$.

Chemistry. Gyrophoric and methylhiascic acids $(\mathrm{K}-, \mathrm{P}-, \mathrm{C}+\mathrm{red})$, mainly in thallus, hymenium, excipulum and pycnidia. Pigment in thallus and apothecia belonging to Cinereorufa-green.

Habitat and distribution. Mostly on soft bark of shaded Acacia heterophylla trees, at 1500$2000 \mathrm{~m}$; also found on Erica, and sometimes overgrowing mosses.

Notes. Within the speciose Micarea peliocarpa group in Réunion, we recognize $M$. borbonica sp. nov. with 7-septate fusiform ascospores, and thus close to $M$. cinerea (see further comments under $M$. borbonica), $M$. boryana sp. nov. with 3-septate narrowly clavate ascospores (see under that species) and also $M$. peliocarpa s. str. which encompasses collections with consistently 3-septate, fusiform ascospores. The size of ascospores falls in the range of European populations as provided by Coppins [2009: (11-)15-23(-24) $\times 3-5(-6) \mu \mathrm{m}]$. However, in the Réunion populations the ascospores are on average wider than in Europe: 13.6-17.0 $\times 4 \cdot 1-4 \cdot 7$ $\mu \mathrm{m}$ in Réunion vs. $12 \cdot 2-22.5 \times 3.5-4 \cdot 2 \mu \mathrm{m}$ in Europe (unpublished results, based on studies of 35 collections).
Specimens examined. Réunion: St-Paul, road to Piton Maïdo, $21^{\circ} 03 \cdot 24^{\prime} \mathrm{S}, 55^{\circ} 21 \cdot 39^{\prime} \mathrm{E}, 1500 \mathrm{~m}$, edge of open woodland, on large Acacia heterophylla, 2008, M. Brand 59488 (h); Cilaos, Plateau du Petit Matarum, path from Le Bloc to Cabane Dufour, $21^{\circ} 06 \cdot 96^{\prime} \mathrm{S}, 55^{\circ} 29 \cdot 22^{\prime} \mathrm{E}$, 1900 m, montane forest, on Acacia heterophylla, 2008, M. Brand 59756 (h); ibid., $21^{\circ} 07 \cdot 3^{\prime}$ S, $55^{\circ} 29 \cdot 2^{\prime} \mathrm{E}, 1420$ $\mathrm{m}$, montane forest, on tree, 2008, P. van den Boom 40282 (h); Piton de la Fournaise, $0.5 \mathrm{~km}$ NW of Gîte du Volcan, $21^{\circ} 12 \cdot 8^{\prime} \mathrm{S}, 55^{\circ} 41 \cdot 18^{\prime} \mathrm{E}, 2040 \mathrm{~m}$, on Acacia heterophylla in wood on N-slope, 2008, M. Brand 58356a, 58356b (h); Forêt de Bébour, path Bélouve to cabane Dufour, $3 \mathrm{~km}$ from Gîte Bélouve, $21^{\circ} 05 \cdot 10^{\prime} \mathrm{S}$, $55^{\circ} 31 \cdot 36^{\prime} \mathrm{E}, 2040 \mathrm{~m}$, wet high ericoid thickets, on Erica, 2008, M. Brand 58864 (h).

\section{Micarea prasina Fr.}

Thallus diffuse, c. $1 \mathrm{~cm}$ across, green, thin $(50 \mu \mathrm{m})$, granular, made of goniocysts $30-$ $40 \mu \mathrm{m}$ diam., round, dark greyish green; goniocysts composed of thin hyphae inspersed with small crystals (melting in boiling water). Photobiont micareoid, cells $c$. 4-6 $\mu \mathrm{m}$.

Apothecia up to $0.3 \mathrm{~mm}$ diam., dark grey to dull black, convex, adnate with narrow base, without any visible margin. Excipulum in lower part of apothecia c. $40 \mu \mathrm{m}$ wide, formed of radiating hyphae. Hypothecium dark grey-brown ( $\mathrm{K}+$ violet). Hymenium to 50 $\mu \mathrm{m}$ high. Paraphyses c. $1 \cdot 2-1 \cdot 3 \mu \mathrm{m}$ thick, branched and anastomosing. Asci c. 40$42 \times 9-12 \mu \mathrm{m}$, tholus of the Micarea-type. Ascospores 8 per ascus, ovoid-ellipsoid, 9.3$12.8 \times 3 \cdot 8-4.3 \mu \mathrm{m},(0-) 1$-septate.

Micropycnidia sparse, white or grey; microconidia $6 \cdot 3-7 \cdot 1 \times 0.9-1 \cdot 1 \mu \mathrm{m}$, narrow fusiform, straight or slightly curved.

Chemistry. Micareic acid. With Sedifoliagrey pigment in inner excipulum, hypothecium and in diffuse streaks in hymenium.

Habitat and distribution. On bark of Acacia heterophylla, intermixed with the related $M$. levicula, and so far only found in natural stands of Acacia heterophylla near the Piton de la Fournaise.

Notes. Our material differs from Micarea prasina, as it is now circumscribed in Europe (Coppins 2009), by the location of the $\mathrm{K}+$ violet pigment in the hypothecium instead of the epihymenium. Otherwise the thallus 
made of finely dissected and coralloid goniocysts, and the production of micareic acid, are diagnostic for $M$. prasina. We refrain from describing a new species on that sole basis. A $\mathrm{K}+$ violet hypothecium is otherwise only known from $M$. endoviolascens Coppins from South Africa (Coppins 1999), easily distinguished by its corticated squamules, and $M$. hypoviolascens Czarnota \& Coppins from a single locality in W Scotland (Czarnota \& Coppins 2005), distinguished by its areolate thallus and production of an unknown substance.

Specimens examined. Réunion: NNW of Piton de la Fournaise, trail along Ravine Savane Cimetière, $21^{\circ} 11 \cdot 6^{\prime} \mathrm{S}, 55^{\circ} 37 \cdot 5^{\prime} \mathrm{E}, 2050 \mathrm{~m}$, mixed forest with mature Acacia heterophylla, on Acacia, 2008, P. van den Boom 39976 (h); Piton de la Fournaise, c. 0.5 km NW of Gîte du Volcan, $21^{\circ} 12 \cdot 82^{\prime} \mathrm{S}, 55^{\circ} 41 \cdot 18^{\prime} \mathrm{E}, 2040 \mathrm{~m}$, on Acacia heterophylla in wood on N-slope, 2008, M. Brand 58355 (h).

\section{Micarea pseudocoppinsii Brand, van den Boom \& Sérus. sp. nov.}

\section{MycoBank No.: MB807679}

Thallus diffuse, small, pale greenish, with convex soralia; apothecia to $0.4 \mathrm{~mm}$, white, pale orange or partly bluish grey, convex; ascospores bacillar-ellipsoid, 11.5-13.0 $\times$ $4 \cdot 2-5 \cdot 7 \mu \mathrm{m},(0-) 3$-septate; production of gyrophoric acid.

Type: Réunion, NNW of Piton de la Fournaise, trail along Ravine Savane Cimetière, $21^{\circ} 12 \cdot 06^{\prime} \mathrm{S}$, $55^{\circ} 41 \cdot 46^{\prime} \mathrm{E}, 2050 \mathrm{~m}$, mixed forest with mature Acacia heterophylla, on Acacia, 28 May 2008, P. van den Boom 39991 (LG-holotype; hb. v.d. Boom, hb. Brand 61466-isotype).

(Fig. 2H)

Thallus diffuse, small $(1.5 \mathrm{~cm}$ across $)$ pale greenish, made of small granules or goniocysts, locally with soralia; goniocysts 18-48 $\mu \mathrm{m}$ diam., round to ovoid, partly coalescing but not coralloid. Photobiont micareoid, $c$. 5-8 $\mu \mathrm{m}$. Soralia sometimes numerous, round, convex, $0.3-0.6 \mathrm{~mm}$ broad; soredia light green, very fine, $11-32 \mu \mathrm{m}$ diam.

Apothecia up to $0.4 \mathrm{~mm}$ diam., white, pale orange or partly bluish grey, convex, adnate with constricted base, without any visible margin. Excipulum formed by radiating, conglutinate hyphae, outer parts pale or bluish grey, pale inside, partly incrusted with gyrophoric acid crystals. Hypothecium colourless. Hymenium c. 50-55 $\mu \mathrm{m}$ high; epihymenium colourless or blue-grey in patches. Paraphyses 1.7-1.9 $\mu \mathrm{m}$ thick, simple or branched, strongly conglutinate. Asci clavate, for example $32-47 \times 11-16 \mu \mathrm{m}$, tholus of the Micarea-type. Ascospores 8 per ascus, bacillarellipsoid, $11 \cdot 5-14.7 \times 4 \cdot 2-5 \cdot 7 \mu \mathrm{m},(0-) 3-$ septate, straight to curved.

Pycnidia not found.

Chemistry. Gyrophoric acid (K-, P-, C+ red), mainly in thallus and soredia, sometimes in excipulum. Pigment in apothecia belonging to Cinereorufa-green.

Etymology. The name refers to another species of Micarea, M. coppinsii, which was dedicated to our talented colleague and friend, Dr Brian J. Coppins.

Habitat and distribution. On soft bark of Acacia heterophylla or overgrowing mosses, between 1500-2050 m elevation.

Notes. Genuine soralia are rare in Micarea. Beside $M$. pseudocoppinsii, they are only known in two other species: $M$. alectorialica, here described as new and easily identified by its black apothecia and production of alectorialic acid, and $M$. coppinsii Tønsberg, also producing gyrophoric acid. The latter species differs in producing methylhiascic acid together with gyrophoric acid, and has fusiform, sometimes slightly clavate, longer as-

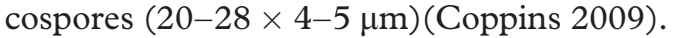
Micarea viridileprosa Coppins \& van den Boom has a bright, green, leproid thallus without clearly delimited soralia and has smaller ascospores $[8-12(-14) \times 2 \cdot 5-4 \cdot 0 \mu \mathrm{m}]$. Micarea pseudocoppinsii is most likely related to the group of $M$. peliocarpa as it has the same type of apothecia, and to M. peliocarpa which differs by its less-developed thallus and lack of soralia.

Additional specimen examined. Réunion: Forêt de Bébour, near Gîte de Bélouve, $21^{\circ} 03 \cdot 74^{\prime} \mathrm{S}, 55^{\circ} 32 \cdot 31^{\prime} \mathrm{E}$, $1520 \mathrm{~m}$, old plantations of Acacia heterophylla trees, on Acacia, 2008, P. van den Boom 39861(h). 


\section{Micarea pseudolignaria Brand, van den Boom \& Sérus. sp. nov.}

\section{MycoBank No.: MB807680}

Thallus muscicolous, areolate, greyish green; apothecia to $0.6 \mathrm{~mm}$, shining black, convex; ascospores ellipsoid, $8 \cdot 0-9.2 \times 3 \cdot 0-3.3 \mu \mathrm{m},(0-) 1$-septate; production of unknown substance.

Type: Réunion, Forêt de Bébour, path Bélouve to cabane Dufour, $21^{\circ} 04 \cdot 77^{\prime} \mathrm{S}, 55^{\circ} 31 \cdot 64^{\prime} \mathrm{E}, 1740 \mathrm{~m}$, soil in ericoid thickets, 2 June 2008, M. Brand 58846 (LG-holotype; hb. v.d. Boom, hb. Brand-isotype).

(Fig. 3C)

Thallus $c .2 \mathrm{~cm}$ across, overgrowing decaying bryophytes, uneven, made of coalescent, $0 \cdot 2-0.3 \mathrm{~mm}$ diam., slightly convex, greyish greenish areolae. Photobiont micareoid, cells c. $5 \mu \mathrm{m}$. Cortex absent but areolae partly covered by a hyaline epinecral layer. Thallus without crystals, except for lower part of photobiont layer more or less opaque due to oily drops and tiny crystals.

Apothecia up to $0.6 \mathrm{~mm}$ diam., shining black, convex without any distinct margin, often coalescing to form compound apothecia. Excipulum with radiating conglutinated hyphae, outer parts brownish to bluish, colourless inside. Hypothecium colourless. Hymenium c. $40 \mu \mathrm{m}$ high, lower part more or less inspersed; epihymenium blue. Paraphyses $1.5 \mu \mathrm{m}$ thick, strongly branched and anastomosing. Asci clavate, c. $35 \times 9 \mu \mathrm{m}$, tholus of the Micarea-type. Ascospores 8 per ascus, ellipsoid, $8 \cdot 0-9 \cdot 2 \times 3 \cdot 0-3.3 \mu \mathrm{m},(0-) 1$-septate, wall c. $0 \cdot 3 \mu \mathrm{m}$ thick.

Micropycnidia superficial (i.e. on thin thallus overgrowing leafy liverworts), c. $75 \mu \mathrm{m}$ diam., wall dark from bluish pigment. Microconidia bacillar, 4.6-5.8 $\times 0.9-1 \cdot 0 \mu \mathrm{m}$.

Chemistry. Unknown 3 in thallus (K-, $\mathrm{P}-$, $\mathrm{C}-$ ), most probably present as tiny oil droplets or crystals. Pigment in apothecia belonging to Cinereorufa-green.

Etymology. The name refers to the widespread M. lignaria, which could be easily confused with this new species.

Habitat and distribution. Only known from the type locality. On soil, among rich stands of Cladonia, in montane ericoid shrubs.
Notes. This new species looks very much like M. lignaria (Ach.) Hedl., also found in a single locality in Réunion, but has smaller 1septate ascospores and a different chemistry. In $M$. lignaria, ascospores are 3-7-septate, $16-28(-38) \times 4 \cdot 3-5 \cdot 7(-7 \cdot 0) \mu \mathrm{m}$, and the thallus produces argopsin (var. lignaria) or unidentified xanthones (var. endoleuca). Furthermore, M. lignaria has a greenish hue in the lower part of the hymenium, which is never inspersed. The rare M. ternaria (Nyl.) Vězda, known only from the Northern Hemisphere, has a similar thallus and apothecia but differs by the lack of lichen substances and (1-)3-septate, $13-22 \times 3 \cdot 5-5 \cdot 0 \mu \mathrm{m}$ ascospores (Coppins 2009).

\section{Micarea sublithinella Brand, van den Boom \& Sérus. sp. nov.}

\section{MycoBank No.: MB807681}

Thallus thin, with flattened rounded areoles, green; apothecia up to $0.4 \mathrm{~mm}$ diam.; ascospores obovoid, $12.5-15 \cdot 0 \times 5 \cdot 0-5.8 \mu \mathrm{m}, 0-1$-septate; production of protolichesterinic acid.

Type: Réunion, NNW of Piton de la Fournaise, trail along Ravine Savane Cimetière, $21^{\circ} 12 \cdot 06^{\prime} \mathrm{S}$, $55^{\circ} 41 \cdot 46^{\prime} \mathrm{E}, 2050 \mathrm{~m}$, mixed forest with mature Acacia heterophylla, on Acacia, 28 May 2008, P. van den Boom 39980 (LG-holotype; hb. v.d. Boom, hb. Brandisotype).

\section{(Fig. 3D)}

Thallus c. $2 \mathrm{~cm}$ across, thin $(25-50 \mu \mathrm{m})$, green, continuous or consisting of flat rounded areoles growing over a thin, slightly shiny film over the substratum. Photobiont micareoid, cells $c$. 5-6 $\mu \mathrm{m}$, thallus with a few crystals.

Apothecia numerous and small, up to 0.4 $\mathrm{mm}$ diam. (deformed apothecia up to 0.5 $\mathrm{mm}$ ), dull, light brownish, broadly adnate, immarginate, convex to semiglobose. Excipulum thin (less than $10 \mu \mathrm{m}$ ). Hypothecium pale. Hymenium c. 55-75 $\mu \mathrm{m}$ high; epihymenium colourless or faintly brownish, with crystals in vertical streaks. Paraphyses 1.0 $\mu \mathrm{m}$ thick, branched. Asci c. 50-70 × 15-16 $\mu \mathrm{m}$, tholus of the Micarea-type. Ascospores 8 per ascus, obovoid (apical part slightly broader), $12.5-15 \cdot 0 \times 5 \cdot 0-5.8 \mu \mathrm{m}, 0-1-$ septate, wall thin $(c .0 \cdot 2 \mu \mathrm{m})$. 
Pycnidia not found.

Chemistry. Protolichesterinic acid (K-, P-, $\mathrm{C}-$ ), with crystals mainly detected in epihymenium, but also present in thallus.

Etymology. The name refers to $M$. lithinella, a widespread species that could be easily confused with this new species.

Habitat and distribution. On wood of rotting trunks, or on trees, including Acacia heterophylla, in montane forests.

Notes. Most characters of Micarea sublithinella fit the the traditional concept of the genus Micarea (sensu Coppins 1983), but the larger asci and production of fatty acid set it apart. In the field it can easily be confused with M. lithinella (Nyl.) Hedl., a widespread species in the Northern Hemisphere, but this species is a pioneer saxicolous species in disturbed habitats, has smaller asci $(35-50 \times 8-$ $13 \mu \mathrm{m})$, smaller and simple ascospores $(6 \cdot 5-$ $9.5 \times 2.5-4.0 \mu \mathrm{m})$ and no compounds detected (Coppins 2009). Species related to M. lithinella, such as M. farinosa Coppins \& Aptroot, also lack compounds.

Additional specimens examined. Réunion: same locality as the type, E. Sérusiaux s. n. (LG); Forêt de Bébour, trail to Takamaka, $21^{\circ} 05 \cdot 9^{\prime} \mathrm{S}, 55^{\circ} 34 \cdot 3^{\prime} \mathrm{E}, 1370 \mathrm{~m}$, wet montane forest, on trees, 2008, P. van den Boom 40872 (h); E of Le Tampon, Forêt de Notre-Dame de la Paix, $21^{\circ} 15 \cdot 1^{\prime} \mathrm{S}, 55^{\circ} 36 \cdot 5^{\prime} \mathrm{E}, 1720 \mathrm{~m}$, montane forest, on tree, 2008, P. van den Boom 40745 (h).

\section{Micarea takamakae Brand, van den Boom \& Sérus. sp. nov.}

\section{MycoBank No.: MB807682}

Thallus semi-endoxylic, made of goniocysts, whitish; apothecia up to $0.2 \mathrm{~mm}$ diam., adnate; ascospores ellipsoid, $8 \cdot 8-10 \cdot 2 \times 3 \cdot 1-3.8 \mu \mathrm{m}, 0-1$-septate; production of unknown substance.

Type: La Réunion, WSW of St-Benoit, along the road to Takamaka, c. $3 \mathrm{~km} \mathrm{SW}$ of Abondance les Hauts, $21^{\circ} 03 \cdot 5^{\prime} \mathrm{S}, 55^{\circ} 38 \cdot 5^{\prime} \mathrm{E}, 620 \mathrm{~m}$, disturbed area with planted trees, on decaying tree, 11 June 2008, P. van den Boom 41009 (LG-holotype; hb. v.d. Boom, hb. Brand-isotype).

(Fig. 3E)

Thallus inconspicuous, diffuse, partly endoxylic on soft, decaying wood, whitish, made of dispersed, round goniocysts, c. 30$75 \mu \mathrm{m}$ diam., either in empty dead cells of the bark or, when superficial, goniocysts covered by clear necrotic tissue. Photobiont micareoid, cells $c$. 5-7 $\mu \mathrm{m}$. Crystals detected in goniocysts.

Apothecia very numerous and small (up to $0.2 \mathrm{~mm}$ diam.), black, adnate with constricted base to nearly stipitate, first flat without any distinct margin, then convex, often forming clusters. Excipulum well developed in under part, made of chondroid tissue; outer part hyaline, inner part locally brown. Hypothecium pale, opaque because of numerous small crystals. Subhymenium reddish brown. Hymenium c. $35 \mu \mathrm{m}$ high; epihymenium dull blue-green and brownish, with small dark granules in K. Paraphyses $1.4 \mu \mathrm{m}$ thick, branched. Asci c. $27-30 \times 11-13 \mu \mathrm{m}$, tholus of the Micarea-type. Ascospores $8 \mathrm{per}$ ascus, ellipsoid, $8 \cdot 8-10 \cdot 2 \times 3 \cdot 1-3 \cdot 8 \mu \mathrm{m}, 0-$ 1-septate, wall c. $0 \cdot 3 \mu \mathrm{m}$ thick.

Pycnidia not found.

Chemistry. Unknown 2, assumed to be confluentic acid or a related compound (K-, $\mathrm{P}-, \mathrm{C}-)$. Pigment in epihymenium belonging to Cinereorufa-green.

Etymology. The name refers to a spot on the northern flank of the island, 'Le Cassé de Takamaka', a landscape of dramatic beauty.

Habitat and distribution. Only known from the type locality, at rather low elevation (620 $\mathrm{m}$ ) in a high rainfall area, on decaying wood of standing trunk.

Notes. Micarea takamakae has an excipulum and hymenium very much akin to those of $M$. erratica, but all other characters are quite different and set it apart from that species. Confluentic acid has never been reported in the genus but all chemical features point to that substance. Small ascospores are a further interesting feature of this new species, amongst the species found on Réunion and not belonging to the $M$. micrococca-prasina aggregate.

\section{Micarea tenuispora Brand, van den Boom \& Sérus. sp. nov.}

MycoBank No.: MB807683 
Thallus very thin to endophloeodal, isidiate or made of isidiiform areolae, isidia small cylindrical to coralloid, up to $0.3 \mathrm{~mm}$ high; apothecia to $0.9 \mathrm{~mm}$, dark grey to black, ascospores acicular, narrowly clavate, 31-35 $\times$ $2 \cdot 2-2 \cdot 5 \mu \mathrm{m}, 3-5$-septate; production of gyrophoric acid.

Type: Réunion, Cirque de Cilaos, Forêt du Grand Matarum, trail to Caverne Dufour, $21^{\circ} 07 \cdot 3^{\prime} \mathrm{S}$, $55^{\circ} 29 \cdot 2^{\prime} \mathrm{E}, 1420 \mathrm{~m}$, montane forest, on Cryptomeria, 31 May 2008, P. van den Boom 40231 (LG-holotype; hb. v.d. Boom, hb. Brand-isotype).

(Fig. 3F)

Thallus to $5 \mathrm{~cm}$ across, pale greenish to brownish, discontinuous, thin (c. $50 \mu \mathrm{m}$ thick), consisting of scattered areolae, soon forming isidia or becoming isidiiform, on thin endo- to epiphloeodal dark bluish hypothallus with narrow, colourless or locally dark brownish or bluish hyphae; mature thallus always with isidiiform areolae (c. $0.2 \mathrm{~mm}$ high, 0.05-0.07 mm thick). Cortex absent, often with thin epinecral layer. Photobiont micareoid. Thallus filled with crystals of gyrophoric acid.

Apothecia up to $0.8 \mathrm{~mm}$ diam., sessile to substipitate, black, usually with a pale margin when young, first flat, without distinct rim, then usually but not always semiglobose. Excipulum with radiating hyphae, varying in colour (often in the same apothecium) from pale (then with crystals) to superficially bluish and centrally light brown. Hypothecium pale brown to dark bluish. Hymenium c. $55 \mu \mathrm{m}$ high; epihymenium greyish bluish in patches. Paraphyses c. $1.3 \mu \mathrm{m}$ thick, branched and anastomosing. Asci c. $44 \times 11 \mu \mathrm{m}$, tholus of the Micarea-type. Ascospores 8 per ascus, in one bundle, sometimes twisted, acicular, apically inflated and tapering towards the base, 31-35 × 2.2-2.5 $\mu \mathrm{m}, 3-5$-septate.

Micropycnidia scarce, inconspicuous, sessile, c. $110 \mu \mathrm{m}$, with blue-green top, brownish wall. Microconidia narrow fusiform, average $3 \cdot 8-4 \cdot 1 \times 1 \cdot 1-1 \cdot 2 \mu \mathrm{m}$.

Chemistry. Gyrophoric acid (K-, $\mathrm{P}-, \mathrm{C}+$ red), mainly in thallus, but also in pale parts of apothecia and in pycnidia. Pigment in thallus and apothecia belonging to Cinereorufagreen. Brown pigment in hypothecium $\mathrm{K}+$ reddish to purple.
Etymology. The name was chosen to emphasize the thin ascospores of this species.

Habitat and distribution. On bark of the exotic Cryptomeria japonica, between 1200$1500 \mathrm{~m}$ elevation, at edges of disturbed natural forests.

Notes. Micarea tenuispora is easily distinguished by its 'isidiate' thallus and 3-5septate ascospores. Isidia or isidiiform thallus areolae are reported in only two species of Micarea, both described here as new. For differences to $M$. isidiosa sp. nov., see under that species.

Additional specimen examined. Réunion: Cilaos, Forêt du Grand Matarum, $21^{\circ} 07 \cdot 17^{\prime} \mathrm{S}, 55^{\circ} 29 \cdot 10^{\prime} \mathrm{E}, 1450 \mathrm{~m}$, disturbed margin of montane forest, on Cryptomeria, 2008, M. Brand 58685 (h).

We are greatly honoured to publish our paper in this special issue of The Lichenologist for the 65th birthday of our most distinguished colleague and friend, and the world expert on Micarea taxonomy, Dr Brian J. Coppins.

Field studies in Réunion were made possible with the help and advice from the Parc National de La Réunion, especially through the courtesy of Mr B. Lequette and Mr J. M. Pausé. Dr Cl. Ah-Peng and Prof. D. Strasberg of the University of La Réunion in Saint-Denis were also very helpful. We thank them all most sincerely. We further thank the Senior Editor of The Lichenologist, Prof. P. D. Crittenden, and the three Editors of this special volume (Dr Alan Fryday, Dr Gintaras Kantvilas and Dr Chris Ellis). Both referees contributed to the final version of this manuscript as their notes and suggestions were very helpful: we thank them warmly.

\section{REFERENCES}

Andersen, H. L. \& Ekman, S. (2005) Disintegration of the Micareaceae (lichenized Ascomycota): a molecular phylogeny based on mitochondrial rDNA sequences. Mycological Research 109: 21-30.

Aptroot, A. (2002) New and interesting lichens and lichenicolous fungi in Brazil. Fungal Diversity 9: 1545.

Baret, S., Rouget, M., Richardson, D. M., Lavergne, C., Egoh, D., Dupont, J. \& Strasberg, D. (2006) Current distribution and potential extent of the most invasive alien species on La Réunion (Indian Ocean, Mascarene Islands). Austral Ecology 31: 747-758.

Bass, D. \& Richards, T. A. (2011) Three reasons to reevaluate fungal diversity 'on Earth and in the ocean'. Fungal Biology Reviews 25: 129-164.

Blackwell, M. (2011) The fungi: 1, 2, 3 . 5.1 million species? American fournal of Botany 98: 426-438.

Cáceres, M. E. S., Mota, D. A., de Jesus, L. S. \& Aptroot, A. (2013) The new lichen species Micarea corallo- 
thallina from Serra da Jibóia, an Atlantic rainforest enclave in Bahia, NE Brazil. Lichenologist 45: 371373.

Cadet, T. (1977) La végétation de l'Ile de La Réunion: étude phytoécologique et phytosociologique. Ph.D. thesis, Université d'Aix-Marseille.

Camargo, A., Avila, L. J., Morando, M. \& Sites, J. W. (2012a) Accuracy and precision of species trees: effects of locus, individual, and base pair sampling on inference of species trees in lizards of the Liolaemus darwinii group (Squamata, Liolaemidae). Systematic Biology 61: 272-288.

Camargo, A., Morando, M., Avila, L. J. \& Sites, J. W. (2012b) Species delimitation with ABC and other coalescent-based methods: a test of accuracy with simulations and an empirical example with lizards of the Liolaemus darwinii complex (Squamata: Liolaemidae). Evolution 66: 2834-2849.

Carstens, B. C., Pelletier, T. A., Reid, N. M. \& Satler, J. D. (2013) How to fail at species delimitation. Molecular Ecology 22: 4369-4383.

Coppins, B. J. (1983) A taxonomic study of the lichen genus Micarea in Europe. Bulletin of the British Museum (Natural History), Botany Series 11(2): 17214.

Coppins, B. J. (1999) Two new species of Micarea from South Africa. Lichenologist 31: 559-565.

Coppins, B. J. (2009) Micarea. In The Lichens of Great Britain and Ireland. (C. W. Smith, A. Aptroot, B. J. Coppins, A. Fletcher, O. L. Gilbert, P. W. James \& P. A. Wolseley, eds): 583-606. London: British Lichen Society.

Coppins, B. J. \& Kantvilas, G. (1990) Studies on Micarea in Australasia I. Four new species from Tasmania. Lichenologist 22: 277-288.

Coppins, B. J. \& Tønsberg, T. (2001) A new xanthonecontaining Micarea from Northwest Europe and the Pacific Northwest of North America. Lichenologist 33: 93-96.

Czarnota, P. (2007) The Lichen Genus Micarea (Lecanorales, Ascomycota) in Poland. Polish Botanical Studies No. 23. Kraków: W. Szafer Institute of Botany, Polish Academy of Sciences.

Czarnota, P. \& Coppins, B. J. (2005) A second Micarea with a hypothecial $\mathrm{K}+$ violet pigment. Lichenologist 37: 477-479.

Czarnota, P. \& Guzow-Krzemińska, B. (2010) A phylogenetic study of the Micarea prasina group shows that Micarea micrococca includes three distinct lineages. Lichenologist 42: 7-21.

Edwards, S. V. (2008) Is a new and general theory of molecular systematics emerging? Evolution 63: 1-19.

Ekman, S., Andersen, H. L. \& Wedin, M. (2008) The limitations of ancestral state reconstruction and the evolution of the ascus in the Lecanorales (Lichenized Ascomycota). Systematic Biology 57: 141-156.

Elix, J. A., Jones, A. J., Laiide, L., Coppins, B. J. \& James, P. W. (1984) Two new diphenyl ethers and a new depside from the lichen Micarea prasina Fr. Australian Fournal of Chemistry 37: 2349-2364.

Fryday, A. M. (2004) New species and records of lichenized fungi from Campbell Island and the Auckland
Islands, New Zealand. Bibliotheca Lichenologica 88: 127-146.

Gaston, K. J. (2000) Global patterns in biodiversity. Nature 405: 220-227.

Harris, R. C. (2009) Four novel lichen taxa in the lichen biota of eastern North America. Opuscula Philolichenum 6: 149-156.

Hawksworth, D. L. (2012) Global species numbers of fungi: are tropical studies and molecular approaches contributing to a more robust estimate? Biodiversity and Conservation 21: 2425-2433.

Honegger, R. (1993) Developmental biology of lichens. Tansley Review No. 60. New Phytologist 125: 659677.

Huneck, S. \& Yoshimura, I. (1996) Identification of Lichen Substances. Berlin, Heidelberg: SpringerVerlag.

Kalb, K. (2007) New or interesting lichens. III. Bibliotheca Lichenologica 95: 297-316.

Kantvilas, G. \& Elix, J. A. (1994) Ramboldia, a new genus in the lichen family Lecanoraceae. Bryologist 97: 296-304.

Knowles, L. L. \& Kubatko, L. S. (2010). Estimating species trees: an introduction to concepts and models. In Estimating Species Trees. Practical and Theoretical Aspects (L. L. Knowles \& L. S. Kutbako, eds): 1-14. Hoboken: Wiley-Blackwell.

Lacoste, M., Delbosc, P. \& Picot, F. (2011) Typologie Descriptive des Habitats Naturels et Semi-naturels de La Réunion, Version Décembre 2011. Rapport technique no 8. Saint-Leu, Réunion: Conservatoire Botanique de Mascarin.

Lagabrielle, E., Rouget, M., Payet, K., Wistebaar, N., Durieux, L., Baret, S., Lombard, A. \& Strasberg, G. (2009) Identifying and mapping biodiversity processes for conservation planning in islands: a case study in Réunion Island (Western Indian Ocean). Biological Conservation 142: 1523-1535.

Lücking, R., Rivas Plata, E., Chaves, J. L., Umaña, L. \& Sipman, H. J. M. (2009) How many tropical lichens are there really? Bibliotheca Lichenologica 100: 399418.

Maddison, W. P. (1997) Gene trees in species trees. Systematic Biology 46: 523-536.

Meyer, B. \& Printzen, C. (2000) Proposal for a standardized nomenclature and characterization of insoluble lichen pigments. Lichenologist 32: 571-583.

Orange, A., James, P. W. \& White, F. J. (2010) Microchemical Methods for the Identification of Lichens. London: British Lichen Society.

Purvis, O. W. \& James, P. W. (1993) Studies on the lichens of the Azores. Part 1. Caldeira Faial. Arquipélago, Life and Marine Sciences 11A: 1-15.

Romeike, J., Friedl, T., Helms, G. \& Ott, S. (2002) Genetic diversity of algal and fungal partners in four species of Umbilicaria (lichenized Ascomycetes) along a transect of the Antarctic Peninsula. Molecular Biology and Evolution 19: 1209-1217.

Schmull, M., Miądlikowska, J., Pelzer, M., StockerWörgötter, E., Hofstetter, V., Fraker, E., Hodkinson, B. P., Reeb, V., Kukwa, M., Lumbsch, H. T., et al. (2011) Phylogenetic affiliations of members of 
the heterogeneous lichen-forming fungi of the genus Lecidea sensu Zahlbruckner (Lecanoromycetes, Ascomycota). Mycologia 103: 983-1003.

Sérusiaux, E., Brand, A. M., Motiejūnaitè, J., Orange, A. \& Coppins, B. J. (2010) Lecidea doliiformis belongs to Micarea, Catillaria alba to Biatora, and Biatora ligni-mollis occurs in western Europe. Bryologist 113: 333-344.

Strasberg, D., Rouget, M., Richardson, D. M., Baret, S., Dupont, J. \& Cowling, R. M. (2005) An assessment of habitat diversity and transformation on La Réunion Island (Mascarene Islands, Indian Ocean) as a basis for identifying broad-scale conservation priorities. Biodiversity and Conservation 14: 3015 3032.
Suija, A., Lõhmus, P. \& Motiejūnaitè, J. (2008) New Estonian records. Lichens and lichenicolous fungi. Folia Cryptogamica Estonica 44: 156-159.

van den Boom, P. P. G. \& Coppins, B. J. (2001) Micarea viridileprosa $\mathrm{sp}$. nov., an overlooked lichen species from Western Europe. Lichenologist 33: 87-91.

van den Boom, P. P. G., Brand, M., Ertz, D., Kalb, K., Magain, N., Masson, D., Schiefelbein, U., Sipman, H. J. M. \& Sérusiaux, E. (2011) Discovering the lichen diversity of a remote tropical island: working list of species collected on Réunion (Mascarene archipelago, Indian Ocean). Herzogia 24: 325-349. 